\title{
Ti (IV) Complexes of Some Heterocyclic Ligands Synthesis, Characterization and Ethylene Polymerization Activity
}

\author{
HAMDI ALI ELAGAB ${ }^{1,2}$ \\ ${ }^{1}$ Albaha University, Faculty of Science and Arts- Almandaq, Albaha, P.O. Box (1988), Saudi Arabia. \\ ${ }^{2}$ Laboratorium für Anorganische Chemie, Universität Bayreuth, \\ Postfach 1012 51, D-95440 Bayreuth, Germany. \\ *Corresponding author E-mail: hamdieez2000@yahoo.com \\ http://dx.doi.org/10.13005/ojc/320177 \\ (Received: September 03, 2015; Accepted: December 09, 2015)

\begin{abstract}
31 complexes of bis - (benzimidazole, benzothiazole and benzoxazole) compounds with $\mathrm{Ti}$ (IV) metal centers were synthesized, characterized, activated with methylalumoxane (MAO) and then tested for catalytic ethylene polymerization. The activities of the various catalysts were found to be functions of the hetero atoms in the ligand frameworks. The highest activity was obtained with 39 / MAO (573 kg PE / mol cat. h). The produced polyethylenes showed high molecular weights (up to $1.5 \times 10^{6} \mathrm{~g} / \mathrm{mol}$ ) and broad molecular weight distributions (PD =65). This could result from different interactions of the MAO counterion with the heteroatoms of the catalyst ligand generating different active sites.
\end{abstract}

Key words: Heterocyclic Ligands, Catalyst, Ethylene Polymerization.

\section{INTRODUCTION}

A review of the literature revealed that 1,2-bis(2-benzothiazolyl)benzene and 1,2-bis(2benzothiazolyl)ethane are frequently used as ligands and a considerable number of their complexes with late transition metals are reported ${ }^{1-6}$. Also, the nickel(II), cobalt(II) and copper(II) coordination chemistry of some tetradentate ligands involving benzothiazole functional groups has been published ${ }^{7}$. In all cases involving benzothiazoles as functional groups the ligands behave as nitrogen donors, except in a few cases involving bridging benzothiazole ${ }^{8}$, in which it is assumed to behave as a bidentate ligand involving both $\mathrm{N}$ and $\mathrm{S}$ donation. The ligand 2, 6-bis (2-benzothiazolyl) pyridine9, 10, has been shown to behave as an N-3 donor in its complexes with manganese (II), iron (II) and nickel (II). 2,6-Bis(benzimidazolyl)pyridine ${ }^{1,11-23}$, and 2,6bis (benzoxazolyl)pyridine ${ }^{24}$, derivatives have been reported as ligands for transition metals in order to investigate the complexes for their structures and properties. 
In polyolefin chemistry, an increasing interest has been focused on the exploration and development of homogeneous transition metal catalysts, as a result of an increasing demand for polyethylene ${ }^{25-30}$. The vanadium complexes of bis(benzimidazole)amine tridentate ligands $[\mathrm{N}, \mathrm{N}, \mathrm{N}]$, were reported as active

\begin{tabular}{|c|c|c|c|c|}
\hline No. & Bridging unit (B) & $x$ & $R_{1}$ & $\mathbf{R}_{2}$ \\
\hline 1 & - & $\mathrm{S}$ & $\mathrm{H}$ & $\mathrm{H}$ \\
\hline 2 & - & 0 & $\mathrm{H}$ & $\mathrm{H}$ \\
\hline 3 & - & $\mathrm{O}$ & $\mathrm{CH}_{3}$ & $\mathrm{H}$ \\
\hline 4 & - & $\mathrm{NH}$ & $\mathrm{H}^{\circ}$ & $\mathrm{H}$ \\
\hline 5 & - & $\mathrm{NH}$ & $\mathrm{CH}_{3}$ & $\mathrm{H}$ \\
\hline 6 & $\mathrm{CH}_{2}$ & $S$ & $\mathrm{H}$ & $\mathrm{H}$ \\
\hline 7 & $\mathrm{CH}_{2}$ & $\mathrm{O}$ & $\mathrm{H}$ & $\mathrm{H}$ \\
\hline 8 & $\mathrm{CH}_{2}$ & $\mathrm{O}$ & $\mathrm{CH}_{3}$ & $\mathrm{H}$ \\
\hline 9 & $\mathrm{CH}_{2}$ & 0 & $\mathrm{H}$ & $\mathrm{CH}_{3}$ \\
\hline 10 & $\mathrm{CH}_{2}$ & $\mathrm{NH}$ & $\mathrm{H}$ & $\mathrm{H}^{\circ}$ \\
\hline 11 & $\mathrm{CH}_{2}$ & $\mathrm{NH}$ & $\mathrm{CH}_{3}$ & $\mathrm{H}$ \\
\hline 12 & $\mathrm{CH}_{2}$ & $\mathrm{NH}$ & $\mathrm{Cl}$ & $\mathrm{H}$ \\
\hline 13 & $\mathrm{CH}_{2} \mathrm{CH}_{2}$ & $\mathrm{~S}$ & $\mathrm{H}$ & $\mathrm{H}$ \\
\hline 14 & $\mathrm{CH}_{2} \mathrm{CH}_{2}$ & $\mathrm{O}$ & $\mathrm{H}$ & $\mathrm{H}$ \\
\hline 15 & $\mathrm{CH}_{2} \mathrm{CH}_{2}$ & $\mathrm{O}$ & $\mathrm{H}$ & $\mathrm{CH}_{3}$ \\
\hline 16 & $\mathrm{CH}_{2} \mathrm{CH}_{2}$ & $\mathrm{O}$ & $\mathrm{CH}_{3}$ & $\mathrm{H}$ \\
\hline 17 & $\mathrm{CH}_{2} \mathrm{CH}_{2}$ & $\mathrm{NH}$ & $\mathrm{H}$ & $\mathrm{H}$ \\
\hline 18 & $\mathrm{CH}_{2} \mathrm{CH}_{2}$ & $\mathrm{NH}$ & $\mathrm{CH}_{3}$ & $\mathrm{H}$ \\
\hline 19 & $\mathrm{CH}_{2} \mathrm{CH}_{2}$ & $\mathrm{NH}$ & $\mathrm{Cl}$ & $\mathrm{H}$ \\
\hline 20 & 1,2-phenylene & $S$ & $\mathrm{H}$ & $\mathrm{H}$ \\
\hline 21 & 1,2-phenylene & 0 & $\mathrm{H}$ & $\mathrm{H}$ \\
\hline 22 & 1,2-phenylene & $\mathrm{O}$ & $\mathrm{CH}_{3}$ & $\mathrm{H}$ \\
\hline 23 & 1,2-phenylene & $\mathrm{O}$ & $\mathrm{H}$ & $\mathrm{CH}_{3}$ \\
\hline 24 & 1,2-phenylene & $\mathrm{NH}$ & $\mathrm{H}$ & $\mathrm{H}$ \\
\hline 25 & 1,2-phenylene & $\mathrm{NH}$ & $\mathrm{CH}_{3}$ & $\mathrm{H}$ \\
\hline 26 & 1,2-phenylene & $\mathrm{NH}$ & $\mathrm{Cl}$ & $\mathrm{H}$ \\
\hline 27 & 4-Me-1,2-phenylene & $S$ & $\mathrm{H}$ & $\mathrm{H}$ \\
\hline 28 & 4-Me-1,2-phenylene & 0 & $\mathrm{H}$ & $\mathrm{H}$ \\
\hline 29 & 4-Me-1,2-phenylene & $\mathrm{NH}$ & $\mathrm{H}$ & $\mathrm{H}$ \\
\hline 30 & 4-Me-1,2-phenylene & $\mathrm{NH}$ & $\mathrm{CH}_{3}$ & $\mathrm{H}$ \\
\hline 31 & 4-Me-1,2-phenylene & $\mathrm{NH}$ & $\mathrm{Cl}$ & $\mathrm{H}$ \\
\hline
\end{tabular}

ethylene polymerization catalysts after activation with simple alkylaluminum compounds ${ }^{31}$ 2,6-Bis(2benzimidazolyl)pyridine zirconium dichloride / MAO polymerizes methylacrylate ${ }^{32}$ Recently, ${ }^{33-39}$ we reported the ethylene polymerization activity of benzimidazole, benzothiazole, benzoxazole and 2-(benzimidazolyl) pyridine titanium zirconium and vanadium complexes. Herein we report on the effect of hetero atom on the activity of zirconium, complexes of bis (benzimidazole), benzothiazole, and benzoxazole), and their behaviour towards ethylene polymerization after activation with methylaluminoxane (MAO).

\section{RESULTS AND DISCUSSION}

\section{General synthesis of ligand precursors}

The condensation reaction of a dicarboxylic acid or an acid anhydride with diamine compound in preheated polyphosphoric acid is a well established procedure for the preparation of the imidazole based ligand precursors ${ }^{20,40,41}$ in high yields (Scheme 1).

\section{Synthesis of titanium complexes 32-62}

The complexes were synthesized according to Scheme 2. The titanium complexes were prepared by ligand displacement reactions. The reaction of the Tetrahydrofuran adducts of titanium tetrachloride with the corresponding ligand precursor in methylene chloride resulted in an immediate colour change and the complexes could be isolated in very high yields $(80-95 \%)$. The complexes were characterized by NMR, mass spectrometry and elemental analysis.

\section{Characterization NMR spectroscopy}

The ligand precursors were characterized by NMR spectroscopy using DMSO and $\mathrm{CD} 2 \mathrm{Cl} 2$ as solvents. Table 2 includes the ${ }^{1} \mathrm{H}$ and ${ }^{13} \mathrm{C}$ NMR data for compounds 1-31. For example, the ${ }^{1} \mathrm{H}$ NMR<smiles>O=C1[B]C(=O)O1</smiles><smiles>[R]c1cc([R])c([R])cc1[Y]</smiles><smiles>[R]c1cc2nc([B]c3nc4cc([R1])c([R])cc4[X]3[H])[nH]c2cc1[R2]</smiles>

Scheme 1: Synthesis of ligand precursors 1-31. 
spectrum of compound 15 (Figure. 1) shows five signals, the doublet at $\mathrm{d}=7.54 \mathrm{ppm}\left[\mathrm{d}, 2 \mathrm{H}, J_{\mathrm{H}, \mathrm{H}}=8.1\right.$ $\mathrm{Hz}$ ] assigned to $\mathrm{H} 2$, the signal at $\mathrm{d}=7.35 \mathrm{ppm}[\mathrm{s}, 2 \mathrm{H}]$ assigned to aromatic protons $\mathrm{H} 1$, the doublet at $\mathrm{d}=$ 7.16ppm [d, $2 \mathrm{H}, J_{\mathrm{H}, \mathrm{H}}=8.1 \mathrm{~Hz}$ ] corresponds to two

$\begin{array}{lllll}\begin{array}{lll}\text { Complex } \\ \text { No. }\end{array} & \begin{array}{l}\text { Bridging } \\ \text { unit (B) }\end{array} & X & \mathbf{R}_{1} & \mathbf{R}_{2}\end{array}$

\begin{tabular}{|c|c|c|c|c|}
\hline 32 & - & $\mathrm{S}$ & $\mathrm{H}$ & $\mathrm{H}$ \\
\hline 33 & - & $\mathrm{O}$ & $\mathrm{H}$ & $\mathrm{H}$ \\
\hline 34 & - & 0 & $\mathrm{CH}_{3}$ & $\mathrm{H}$ \\
\hline 35 & - & $\mathrm{NH}$ & $\mathrm{H}^{3}$ & $\mathrm{H}$ \\
\hline 36 & - & $\mathrm{NH}$ & $\mathrm{CH}_{3}$ & $\mathrm{H}$ \\
\hline 37 & $\mathrm{CH} 2$ & $S$ & $\mathrm{H}^{3}$ & $\mathrm{H}$ \\
\hline 38 & $\mathrm{CH} 2$ & 0 & $\mathrm{H}$ & $\mathrm{H}$ \\
\hline 39 & $\mathrm{CH} 2$ & 0 & $\mathrm{CH}_{3}$ & $\mathrm{H}$ \\
\hline 40 & $\mathrm{CH} 2$ & 0 & $\mathrm{H}$ & $\mathrm{CH}_{3}$ \\
\hline 41 & $\mathrm{CH} 2$ & $\mathrm{NH}$ & $\mathrm{H}$ & $\mathrm{H}$ \\
\hline 42 & $\mathrm{CH} 2$ & $\mathrm{NH}$ & $\mathrm{CH}_{3}$ & $\mathrm{H}$ \\
\hline 43 & $\mathrm{CH} 2$ & $\mathrm{NH}$ & $\mathrm{Cl}$ & $\mathrm{H}$ \\
\hline 44 & $\mathrm{CH} 2 \mathrm{CH} 2$ & $S$ & $\mathrm{H}$ & $\mathrm{H}$ \\
\hline 45 & $\mathrm{CH} 2 \mathrm{CH} 2$ & $\mathrm{O}$ & $\mathrm{H}$ & $\mathrm{H}$ \\
\hline 46 & $\mathrm{CH} 2 \mathrm{CH} 2$ & $\mathrm{O}$ & $\mathrm{CH}_{3}$ & $\mathrm{H}$ \\
\hline 47 & $\mathrm{CH} 2 \mathrm{CH} 2$ & 0 & $\mathrm{H}^{3}$ & $\mathrm{CH}_{3}$ \\
\hline 48 & $\mathrm{CH} 2 \mathrm{CH} 2$ & $\mathrm{NH}$ & $\mathrm{H}$ & $\mathrm{H}^{3}$ \\
\hline 49 & $\mathrm{CH} 2 \mathrm{CH} 2$ & $\mathrm{NH}$ & $\mathrm{CH}_{3}$ & $\mathrm{H}$ \\
\hline 50 & $\mathrm{CH} 2 \mathrm{CH} 2$ & $\mathrm{NH}$ & $\mathrm{Cl}^{3}$ & $\mathrm{H}$ \\
\hline 51 & 1,2-phenylene & $S$ & $\mathrm{H}$ & $\mathrm{H}$ \\
\hline 52 & 1,2-phenylene & $\mathrm{O}$ & $\mathrm{H}$ & $\mathrm{H}$ \\
\hline 53 & 1,2-phenylene & $\mathrm{O}$ & $\mathrm{CH}_{3}$ & $\mathrm{H}$ \\
\hline 54 & 1,2-phenylene & 0 & $\mathrm{H}^{3}$ & $\mathrm{CH}_{3}$ \\
\hline 55 & 1,2-phenylene & $\mathrm{NH}$ & $\mathrm{H}$ & $\mathrm{H}^{\circ}$ \\
\hline 56 & 1,2-phenylene & $\mathrm{NH}$ & $\mathrm{CH}_{3}$ & $\mathrm{H}$ \\
\hline 57 & 1,2-phenylene & $\mathrm{NH}$ & $\mathrm{Cl}$ & $\mathrm{H}$ \\
\hline 58 & 4-Me-1,2-phenylene & $S$ & $\mathrm{H}$ & $\mathrm{H}$ \\
\hline 59 & 4-Me-1,2-phenylene & 0 & $\mathrm{H}$ & $\mathrm{H}$ \\
\hline 60 & 4-Me-1,2-phenylene & $\mathrm{NH}$ & $\mathrm{H}$ & $\mathrm{H}$ \\
\hline 61 & 4-Me-1,2-phenylene & $\mathrm{NH}$ & $\mathrm{CH}_{3}$ & $\mathrm{H}$ \\
\hline 62 & 4-Me-1,2-phenylene & $\mathrm{NH}$ & $\mathrm{Cl}^{3}$ & $\mathrm{H}$ \\
\hline
\end{tabular}

protons $\mathrm{H} 3$. At $d=3.54 \mathrm{ppm}$ a singlet assigned to $\mathrm{H} 4$, and the signal upfield at $\mathrm{d}=2.50 \mathrm{ppm}$ assigned to the $\mathrm{s} 1 \mathrm{x}$ protons of the methyl groups.

The ${ }^{13} \mathrm{C}$ NMR spectrum of compound 15 (Figure. 2) shows nine signals. The two signals downfield at $d=165.5 \mathrm{ppm}$ and at $d=149.4 \mathrm{ppm}$ correspond to the carbon atoms 7 and 1 respectively. Each of the five signals at $d=141.8,134.43,125.9$, 119.7 , and $109.9 \mathrm{ppm}$ corresponds to two carbon atoms (6, 3, 4, 5 and 2 respectively) of the aromatic rings. The carbon atoms of the bridging group appear upfield at $d=25.7 \mathrm{ppm}$. The methyl carbon appears at $d=21.3 \mathrm{ppm}$

The ${ }^{1} \mathrm{H}$ NMR spectrum of complex 46 (Figure.3) shows four resonance signals. The doublet at $\mathrm{d}=7.52 \mathrm{ppm}\left[\mathrm{d}, 2 \mathrm{H}, J_{\mathrm{H}, \mathrm{H}}=8.1 \mathrm{~Hz}\right]$ assigned to $\mathrm{H} 2$, the signal at $d=7.48 \mathrm{ppm}[\mathrm{s}, 2 \mathrm{H}$,] can be assigned to $\mathrm{H} 1$, the doublet at $\mathrm{d}=7.14 \mathrm{ppm}$ is assigned toH3 . The bridging group protons $\mathrm{H} 4$ can be observed as a singlet at $d=3.50 \mathrm{ppm}$. The singlet at $d=2.42 \mathrm{ppm}$ is assigned to the methyl protons $\mathrm{H} 5$.

The ${ }^{13} \mathrm{C}$ NMR spectrum of complex 46 (Figure. 4) shows nine resonance signals each corresponding to two carbon atoms. The signals at $d=167.2,149.7,142.3,136.0,127.6,119.5,111.2$, 25.6 and $21.4 \mathrm{ppm}$ can be assigned to the carbon atoms $\mathrm{C} 7, \mathrm{C} 1, \mathrm{C} 6, \mathrm{C} 3, \mathrm{C} 4, \mathrm{C} 5, \mathrm{C} 2, \mathrm{C} 8$, and $\mathrm{C} 9$ respectively.

\section{Mass spectroscopy}

The ligand precursors were also characterized by their mass spectra. The mass spectrum of compound 15 shows the molecular ion peak $\mathrm{m} / \mathrm{z}=292$ and $\mathrm{m} / \mathrm{z}=146\left(\mathrm{M}^{\circ}+\mathrm{C}_{9} \mathrm{H}_{8} \mathrm{NO}\right)$. The ion with the mass $\mathrm{m} / \mathrm{z}=132$ can be assigned to $\left(\mathrm{C}_{8} \mathrm{H}_{6} \mathrm{NO}\right)$, (the full fragmentation pattern is shown in Figure 5).<smiles>[R]c1cc2nc([Z]c3nc([X])c([R])cc3[X])[nH]c2cc1[R]</smiles>

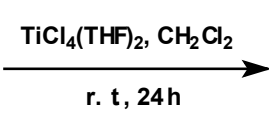<smiles></smiles>

Scheme 2: Synthesis of the coordination compounds 32-62 

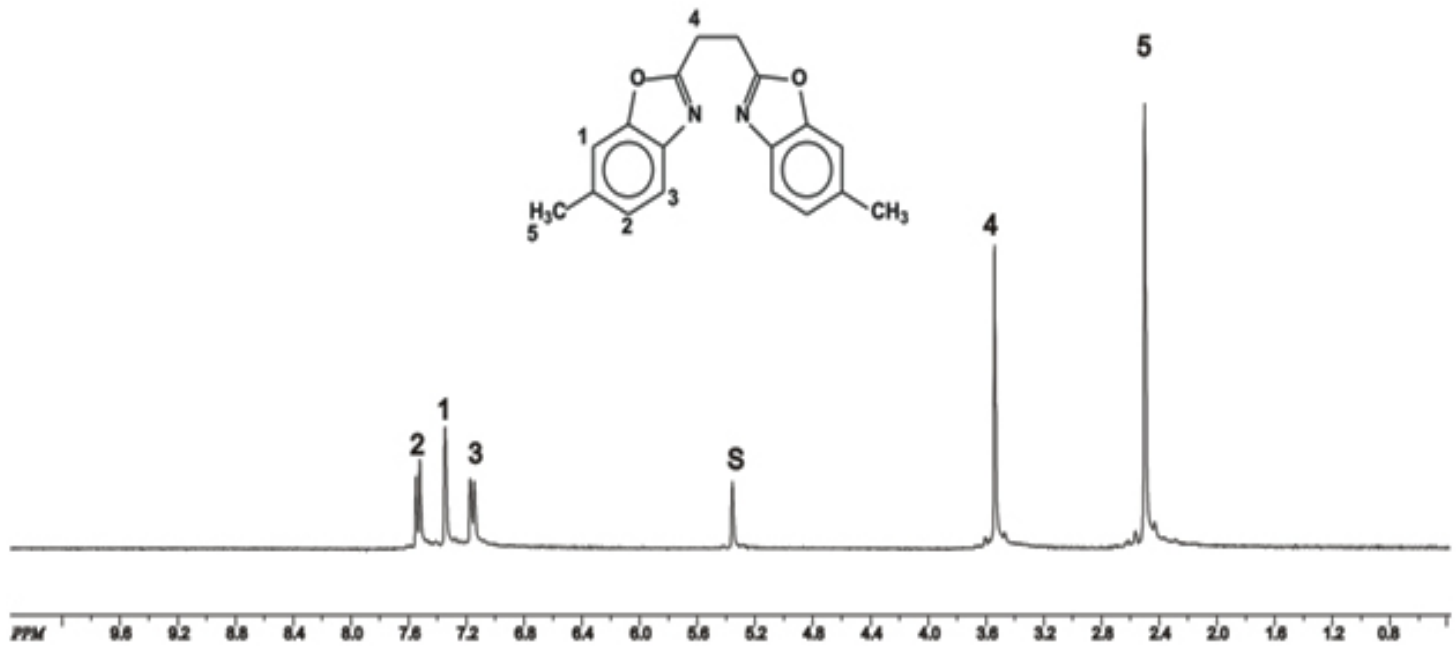

Fig.1: ${ }^{1} \mathrm{H}$ NMR spectrum of compound 15 in deuterated $\mathrm{CD}_{2} \mathrm{Cl}_{2}$

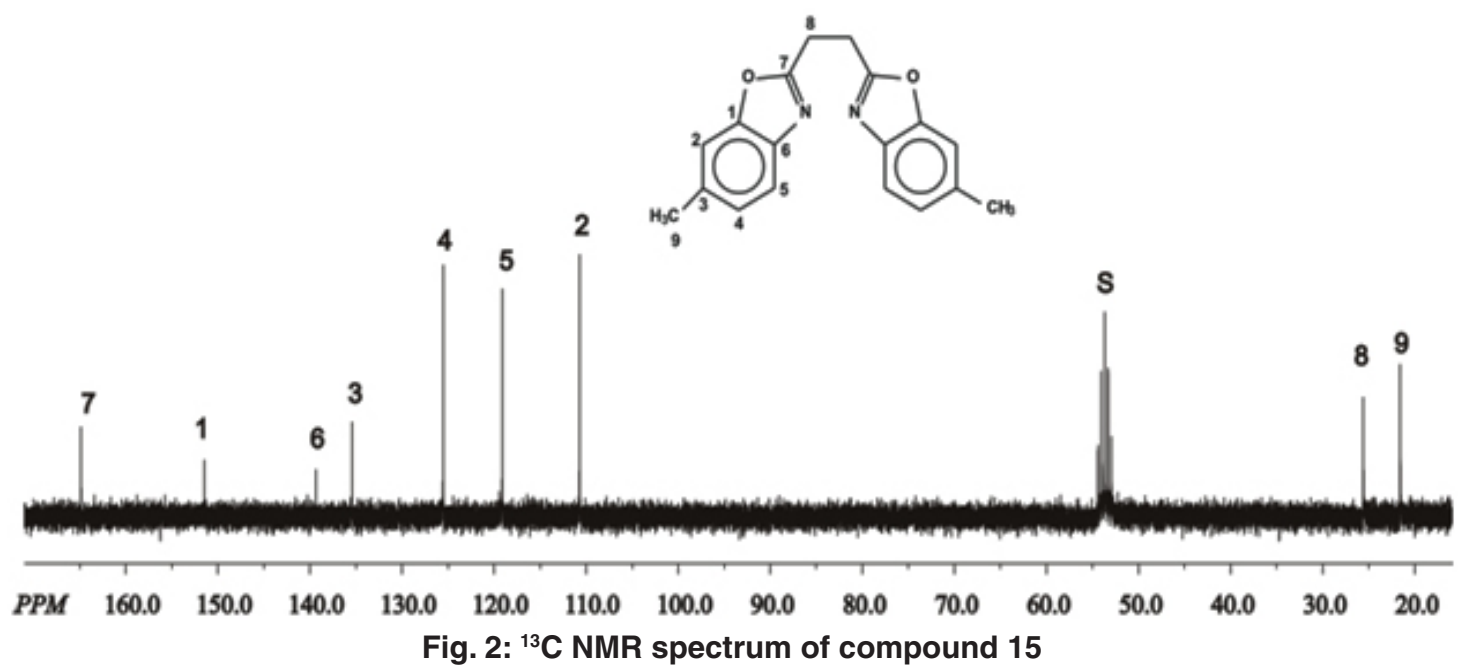

Fig. 2: ${ }^{13} \mathrm{C}$ NMR spectrum of compound 15

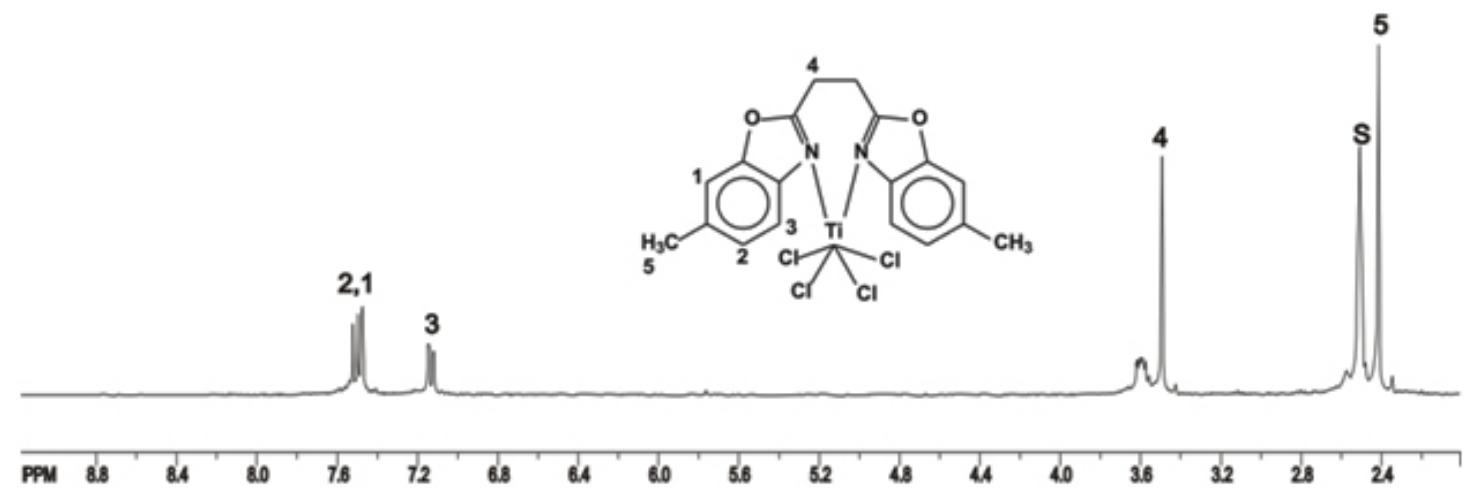

Fig. 3: ${ }^{1} \mathrm{H}$ NMR spectrum of complex 46 
Figure 6 shows the mass spectrum of complex 46. The molecular ion peak $\mathrm{m} / \mathrm{z}=482$. The ion with $\mathrm{m} / \mathrm{z}=449$ represents the loss of one chloride, the ions with $\mathrm{m} / \mathrm{z}=411$ result from the loss of two chlorides. The ion with $\mathrm{m} / \mathrm{z}=292$ represents the mass of the free ligand.
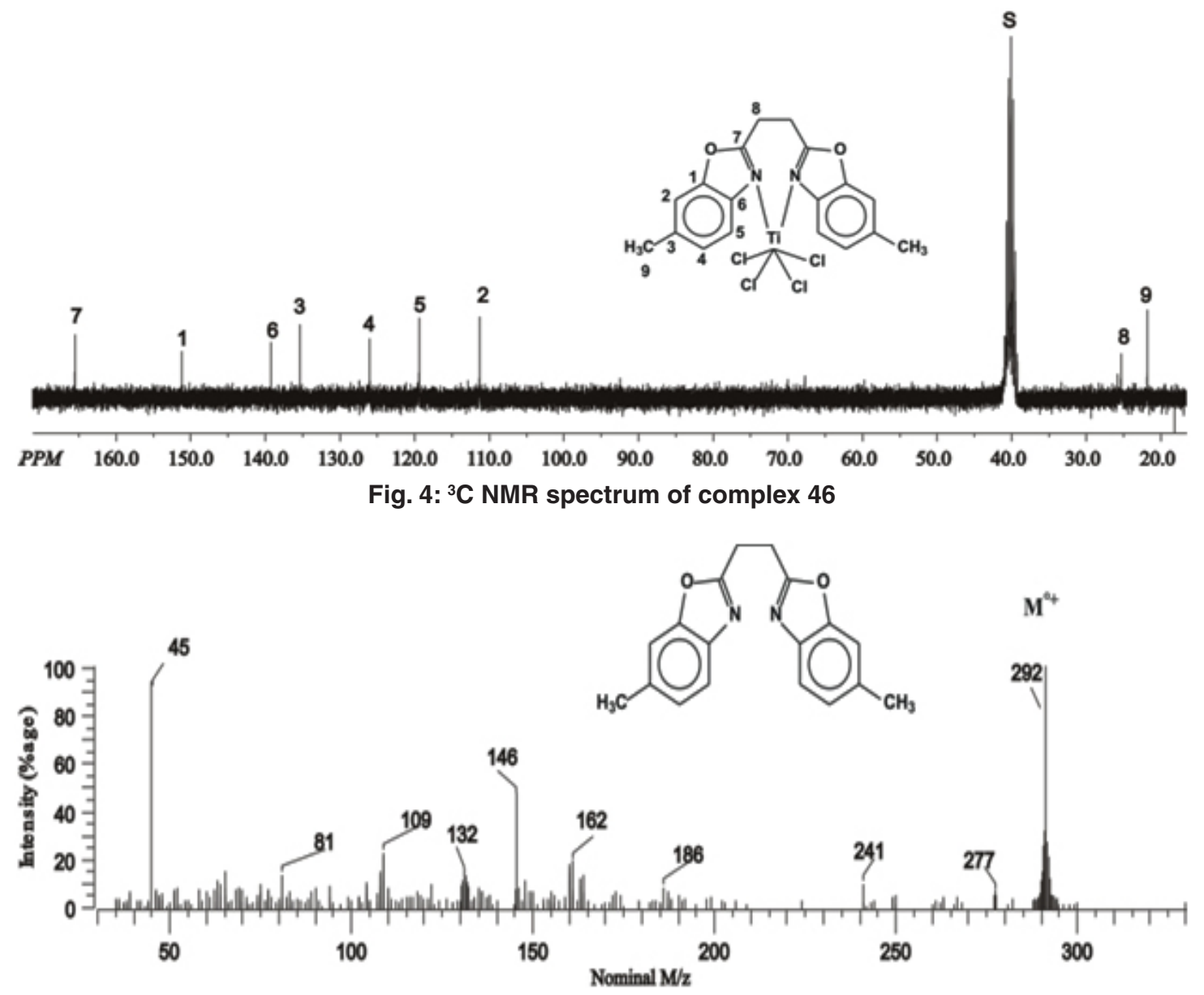

Fig. 5: Mass spectrum of compound 15

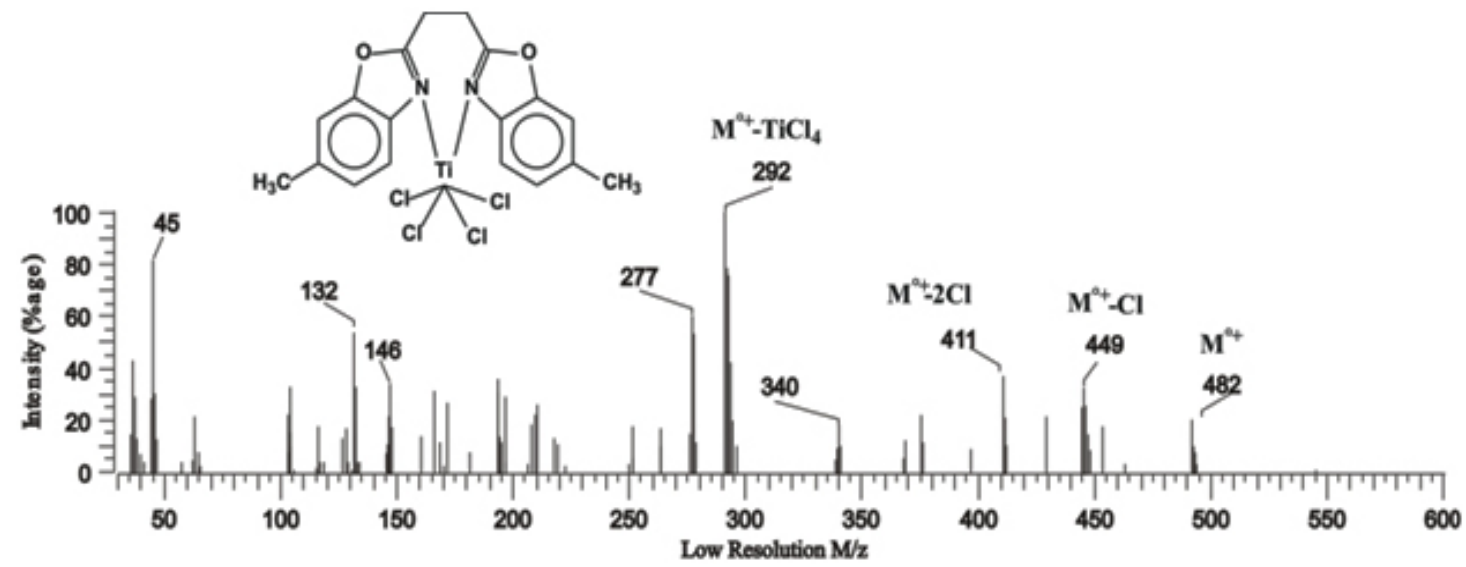

Fig. 6: Mass spectrum of complex 46 
Table 1:Elemental analysis data for heterocycles and their complexes.

\begin{tabular}{|c|c|c|c|c|c|c|c|}
\hline \multirow{2}{*}{$\begin{array}{l}\text { Compound } \\
\text { No. }\end{array}$} & \multirow{2}{*}{$\begin{array}{l}\text { General } \\
\text { Formula }\end{array}$} & \multicolumn{3}{|c|}{ Calculated } & \multicolumn{3}{|c|}{ Found } \\
\hline & & C & $\mathbf{H}$ & $\mathbf{N}$ & C & $\mathbf{H}$ & $\mathbf{N}$ \\
\hline 1 & $\mathrm{C}_{14} \mathrm{H}_{8} \mathrm{~N}_{2} \mathrm{~S}_{2}$ & 62.7 & 3.0 & 10.4 & 62.9 & 2.8 & 10.6 \\
\hline 2 & $\mathrm{C}_{14}^{14} \mathrm{H}_{8}^{8} \mathrm{~N}_{2}^{2} \mathrm{O}_{2}^{2}$ & 71.2 & 3.4 & 11.9 & 70.8 & 3.6 & 12.1 \\
\hline 3 & $\mathrm{C}_{16}^{14} \mathrm{H}_{12}^{8} \mathrm{~N}_{2} \mathrm{O}_{2}^{2}$ & 72.7 & 4.5 & 10.6 & 72.4 & 4.7 & 10.8 \\
\hline 4 & $\mathrm{C}_{14} \mathrm{H}_{10} \mathrm{~N}_{4}$ & 71.8 & 4.3 & 23.9 & 71.6 & 4.5 & 24.1 \\
\hline 5 & $\mathrm{C}_{16}^{14} \mathrm{H}_{14} \mathrm{~N}_{4}^{4}$ & 73.3 & 5.3 & 21.4 & 72.9 & 5.5 & 21.1 \\
\hline 6 & $\mathrm{C}_{15}^{16} \mathrm{H}_{10} \mathrm{~N}_{2} \mathrm{~S}_{2}$ & 63.8 & 3.5 & 9.9 & 63.6 & 3.4 & 10.2 \\
\hline 7 & $\mathrm{C}_{15} \mathrm{H}_{10} \mathrm{~N}_{2} \mathrm{O}_{2}$ & 72.0 & 4.0 & 11.2 & 71.8 & 4.2 & 11.4 \\
\hline 8 & $\mathrm{C}_{17} \mathrm{H}_{14} \mathrm{~N}_{2} \mathrm{O}_{2}$ & 73.4 & 5.0 & 10.1 & 73.6 & 5.1 & 9.8 \\
\hline 9 & $\mathrm{C}_{17} \mathrm{H}_{14} \mathrm{~N}_{2} \mathrm{O}_{2}^{2}$ & 73.4 & 5.0 & 10.1 & 73.6 & 5.1 & 9.8 \\
\hline 10 & $\mathrm{C}_{15} \mathrm{H}_{12} \mathrm{~N}_{4}^{2}$ & 72.6 & 4.8 & 22.6 & 71.8 & 4.6 & 22.4 \\
\hline 11 & $\mathrm{C}_{17}^{15} \mathrm{H}_{16}^{12} \mathrm{~N}_{4}^{4}$ & 73.9 & 5.8 & 20.3 & 73.7 & 6.0 & 20.1 \\
\hline 12 & $\mathrm{C}_{15} \mathrm{H}_{10} \mathrm{~N}_{4}^{4} \mathrm{Cl}_{2}$ & 64.9 & 4.1 & 9.5 & 65.2 & 4.4 & 9.1 \\
\hline 13 & $\mathrm{C}_{16}^{15} \mathrm{H}_{12} \mathrm{~N}_{2} \mathrm{~S}_{2}^{2}$ & 64.9 & 4.1 & 9.5 & 65.2 & 3.9 & 9.6 \\
\hline 14 & $\mathrm{C}_{16}^{16} \mathrm{H}_{12} \mathrm{~N}_{2} \mathrm{O}_{2}$ & 72.7 & 4.6 & 10.6 & 72.9 & 4.5 & 10.5 \\
\hline 15 & $\mathrm{C}_{18}^{16} \mathrm{H}_{16}^{12} \mathrm{~N}_{2}^{2} \mathrm{O}_{2}^{2}$ & 74.0 & 5.5 & 9.6 & 73.7 & 5.8 & 9.9 \\
\hline 16 & $\mathrm{C}_{18} \mathrm{H}_{16} \mathrm{~N}_{2} \mathrm{O}_{2}$ & 74.0 & 5.5 & 9.6 & 73.8 & 5.7 & 9.6 \\
\hline 17 & $\mathrm{C}_{16} \mathrm{H}_{14} \mathrm{~N}_{4}$ & 73.3 & 5.3 & 21.4 & 72.9 & 5.4 & 21.4 \\
\hline 18 & $\mathrm{C}_{18}^{16} \mathrm{H}_{18} \mathrm{~N}_{4}^{4}$ & 74.5 & 6.2 & 19.3 & 74.8 & 5.9 & 19.6 \\
\hline 19 & $\mathrm{C}_{16} \mathrm{H}_{12} \mathrm{~N}_{4} \mathrm{Cl}_{2}$ & 58.0 & 3.6 & 16.9 & 58.2 & 3.7 & 17.1 \\
\hline 20 & $\mathrm{C}_{20}^{16} \mathrm{H}_{12} \mathrm{~N}_{2} \mathrm{~S}_{2}$ & 68.8 & 3.5 & 8.1 & 69.7 & 3.5 & 8.2 \\
\hline 21 & $\mathrm{C}_{20} \mathrm{H}_{12} \mathrm{~N}_{2} \mathrm{O}_{2}$ & 76.9 & 3.9 & 9.0 & 77.1 & 3.7 & 8.8 \\
\hline 22 & $\mathrm{C}_{22} \mathrm{H}_{16} \mathrm{~N}_{2} \mathrm{O}_{2}$ & 77.7 & 4.7 & 8.2 & 77.7 & 4.7 & 8.4 \\
\hline 23 & $\mathrm{C}_{22} \mathrm{H}_{16} \mathrm{~N}_{2} \mathrm{O}_{2}$ & 77.7 & 4.7 & 8.2 & 77.7 & 4.7 & 8.4 \\
\hline 24 & $\mathrm{C}_{20} \mathrm{H}_{14} \mathrm{~N}_{4}$ & 77.4 & 4.5 & 18.1 & 77.4 & 4.5 & 18.1 \\
\hline 25 & $\mathrm{C}_{22} \mathrm{H}_{18} \mathrm{~N}_{4}$ & 78.1 & 5.3 & 16.6 & 78.6 & 5.2 & 17.1 \\
\hline 26 & $\mathrm{C}_{20} \mathrm{H}_{12} \mathrm{~N}_{4} \mathrm{Cl}_{2}$ & 63.3 & 3.2 & 14.8 & 64.1 & 3.5 & 15.2 \\
\hline 27 & $\mathrm{C}_{21} \mathrm{H}_{14} \mathrm{~N}_{2}^{4} \mathrm{~S}_{2}$ & 70.4 & 3.9 & 7.8 & 69.8 & 4.1 & 7.5 \\
\hline 28 & $\mathrm{C}_{21} \mathrm{H}_{14} \mathrm{~N}_{2} \mathrm{O}_{2}$ & 77.3 & 4.3 & 8.6 & 76.9 & 4.6 & 8.9 \\
\hline 29 & $\mathrm{C}_{21} \mathrm{H}_{16} \mathrm{~N}_{4}$ & 77.8 & 4.9 & 17.3 & 78.1 & 5.2 & 17.6 \\
\hline 30 & $\mathrm{C}_{23} \mathrm{H}_{20} \mathrm{~N}_{4}^{4}$ & 78.4 & 5.7 & 15.9 & 78.1 & 5.5 & 16.2 \\
\hline 31 & $\mathrm{C}_{21} \mathrm{H}_{14} \mathrm{~N}_{4}^{4} \mathrm{Cl}_{2}$ & 64.1 & 3.6 & 14.2 & 64.5 & 3.9 & 13.9 \\
\hline 32 & $\mathrm{C}_{14}^{21} \mathrm{H}_{8} \mathrm{~N}_{2} \mathrm{~S}_{2}^{2} \mathrm{TiCl}_{4}$ & 36.7 & 1.8 & 6.1 & 36.2 & 1.7 & 5.9 \\
\hline 33 & $\mathrm{C}_{14}^{14} \mathrm{H}_{8}^{8} \mathrm{~N}_{2}^{2} \mathrm{O}_{2}^{2} \mathrm{TiCl}_{4}^{4}$ & 39.4 & 1.9 & 6.6 & 39.8 & 1.8 & 6.7 \\
\hline 34 & $\mathrm{C}_{16} \mathrm{H}_{12} \mathrm{~N}_{2} \mathrm{O}_{2} \mathrm{TiCl}_{4}^{4}$ & 42.3 & 2.6 & 6.2 & 41.9 & 2.3 & 5.9 \\
\hline 35 & $\mathrm{C}_{14}^{16} \mathrm{H}_{10} \mathrm{~N}_{4} \mathrm{TiCl}_{4}^{2}$ & 39.6 & 2.4 & 13.2 & 39.1 & 2.6 & 13.7 \\
\hline 36 & $\mathrm{C}_{16}^{14} \mathrm{H}_{14} \mathrm{~N}_{4}^{4} \mathrm{TiCl}_{4}^{4}$ & 42.4 & 3.1 & 12.4 & 42.7 & 2.9 & 12.2 \\
\hline 37 & $\mathrm{C}_{15} \mathrm{H}_{10} \mathrm{~N}_{2} \mathrm{~S}_{2} \mathrm{TiCl}_{4}$ & 38.1 & 2.1 & 5.9 & 38.4 & 2.1 & 5.6 \\
\hline 38 & $\mathrm{C}_{15} \mathrm{H}_{10} \mathrm{~N}_{2} \mathrm{O}_{2} \mathrm{TiCl}_{4}^{4}$ & 40.9 & 2.3 & 6.4 & 40.8 & 2.0 & 6.4 \\
\hline 39 & $\mathrm{C}_{17} \mathrm{H}_{14} \mathrm{~N}_{2} \mathrm{O}_{2} \mathrm{TiCl}_{4}^{4}$ & 42.7 & 2.9 & 5.9 & 42.3 & 3.0 & 5.4 \\
\hline 40 & $\mathrm{C}_{17} \mathrm{H}_{14} \mathrm{~N}_{2} \mathrm{O}_{2} \mathrm{TiCl}_{4}^{4}$ & 42.7 & 2.9 & 5.9 & 42.6 & 2.7 & 5.5 \\
\hline 41 & $\mathrm{C}_{15} \mathrm{H}_{12} \mathrm{~N}_{4} \mathrm{TiCl}_{4}$ & 41.9 & 2.8 & 13.0 & 42.2 & 2.6 & 13.4 \\
\hline 42 & $\mathrm{C}_{17} \mathrm{H}_{16} \mathrm{~N}_{4}^{4} \mathrm{TiCl}_{4}^{4}$ & 43.8 & 3.4 & 12.0 & 43.5 & 3.8 & 11.7 \\
\hline 43 & $\mathrm{C}_{15} \mathrm{H}_{10} \mathrm{~N}_{4} \mathrm{Cl}_{2} \mathrm{TiCl}_{4}$ & 35.5 & 2.0 & 11.0 & 35.2 & 2.1 & 10.8 \\
\hline 44 & $\mathrm{C}_{16} \mathrm{H}_{12} \mathrm{~N}_{2} \mathrm{~S}_{2}^{2} \mathrm{TiCl}_{4}^{4}$ & 39.5 & 2.5 & 5.8 & 39.3 & 2.5 & 5.4 \\
\hline 45 & $\mathrm{C}_{16} \mathrm{H}_{12} \mathrm{~N}_{2} \mathrm{O}_{2} \mathrm{TiCl}_{4}^{4}$ & 42.3 & 2.6 & 6.2 & 42.0 & 2.2 & 5.9 \\
\hline
\end{tabular}




\begin{tabular}{llllllll}
46 & $\mathrm{C}_{18} \mathrm{H}_{16} \mathrm{~N}_{2} \mathrm{O}_{2} \mathrm{TiCl}_{4}$ & 44.8 & 3.3 & 5.8 & 44.7 & 3.4 & 5.6 \\
47 & $\mathrm{C}_{18} \mathrm{H}_{16} \mathrm{~N}_{2} \mathrm{O}_{2} \mathrm{TiCl}_{4}$ & 44.8 & 3.3 & 5.8 & 45.2 & 3.1 & 5.9 \\
48 & $\mathrm{C}_{16} \mathrm{H}_{14} \mathrm{~N}_{4} \mathrm{TiCl}_{4}$ & 42.5 & 3.1 & 12.4 & 42.3 & 3.3 & 12.8 \\
49 & $\mathrm{C}_{18} \mathrm{H}_{18} \mathrm{~N}_{4} \mathrm{TiCl}_{4}$ & 45.0 & 3.8 & 11.7 & 45.6 & 3.5 & 11.4 \\
50 & $\mathrm{C}_{16} \mathrm{H}_{12} \mathrm{~N}_{4} \mathrm{Cl}_{2} \mathrm{TiCl}_{4}$ & 36.9 & 2.3 & 10.7 & 36.8 & 2.6 & 10.9 \\
51 & $\mathrm{C}_{20} \mathrm{H}_{12} \mathrm{~N}_{2} \mathrm{~S}_{2} \mathrm{TiCl}_{4}$ & 44.9 & 2.2 & 5.2 & 45.3 & 1.9 & 4.9 \\
52 & $\mathrm{C}_{20} \mathrm{H}_{12} \mathrm{~N}_{2} \mathrm{O}_{2} \mathrm{TiCl}_{4}$ & 47.8 & 2.4 & 6.6 & 47.4 & 2.7 & 6.8 \\
53 & $\mathrm{C}_{22} \mathrm{H}_{16} \mathrm{~N}_{2} \mathrm{O}_{2} \mathrm{TiCl}_{4}$ & 49.8 & 3.0 & 5.3 & 49.7 & 2.9 & 5.5 \\
54 & $\mathrm{C}_{22} \mathrm{H}_{16} \mathrm{~N}_{2} \mathrm{O}_{2} \mathrm{TiCl}_{4}$ & 49.8 & 3.0 & 5.3 & 49.2 & 3.3 & 5.6 \\
55 & $\mathrm{C}_{20} \mathrm{H}_{14} \mathrm{~N}_{4} \mathrm{TiCl}_{4}$ & 48.0 & 2.8 & 11.2 & 48.5 & 2.4 & 11.5 \\
56 & $\mathrm{C}_{22} \mathrm{H}_{18} \mathrm{~N}_{4} \mathrm{TiCl}_{4}$ & 50.0 & 3.4 & 10.6 & 49.8 & 3.5 & 10.1 \\
57 & $\mathrm{C}_{20} \mathrm{H}_{12} \mathrm{~N}_{4} \mathrm{Cl}_{2} \mathrm{TiCl}_{4}$ & 42.3 & 2.1 & 9.9 & 42.5 & 1.9 & 9.5 \\
58 & $\mathrm{C}_{21} \mathrm{H}_{14} \mathrm{~N}_{2} \mathrm{~S}_{2} \mathrm{TiCl}_{4}$ & 46.0 & 2.6 & 5.1 & 46.3 & 2.9 & 4.8 \\
59 & $\mathrm{C}_{21} \mathrm{H}_{14} \mathrm{~N}_{2} \mathrm{O}_{2} \mathrm{TiCl}_{4}$ & 48.8 & 2.7 & 5.4 & 47.9 & 3.0 & 5.2 \\
60 & $\mathrm{C}_{21} \mathrm{H}_{16} \mathrm{~N}_{4} \mathrm{TiCl}_{4}$ & 49.0 & 3.1 & 10.9 & 48.7 & 3.4 & 10.7 \\
61 & $\mathrm{C}_{23} \mathrm{H}_{20} \mathrm{~N}_{4} \mathrm{TiCl}_{4}$ & 50.9 & 3.7 & 10.3 & 51.3 & 3.4 & 10.6 \\
62 & $\mathrm{C}_{21} \mathrm{H}_{14} \mathrm{~N}_{4} \mathrm{Cl}_{2} \mathrm{TiCl}_{4}$ & 43.3 & 2.4 & 9.6 & 43.7 & 2.6 & 9.4 \\
\hline
\end{tabular}

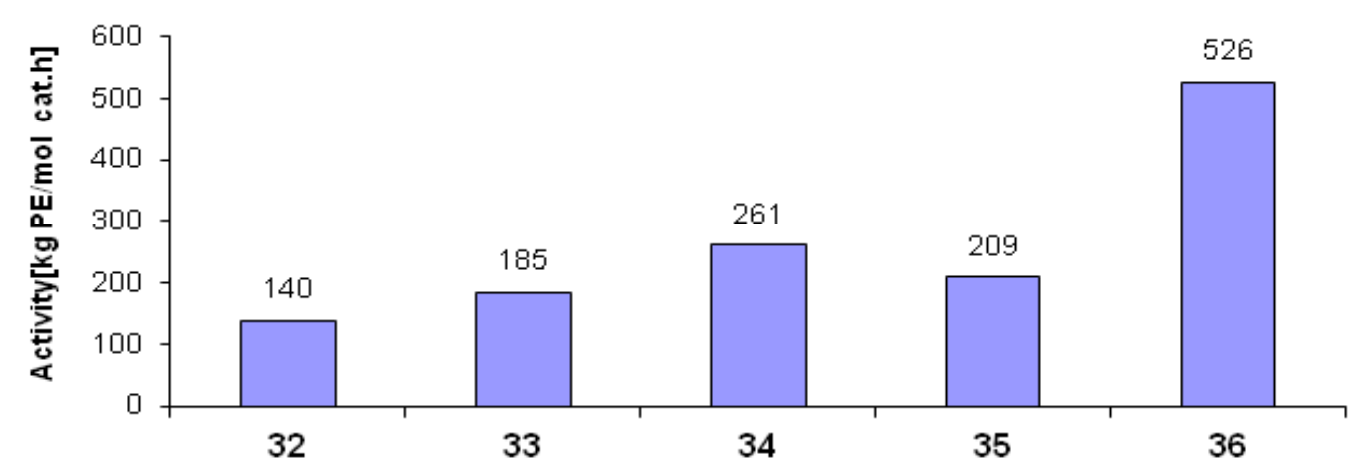

Fig. 7: Activities of bis (benzothiazolyl, benzoxazolyl, benzimidazolyl) titanium complexes

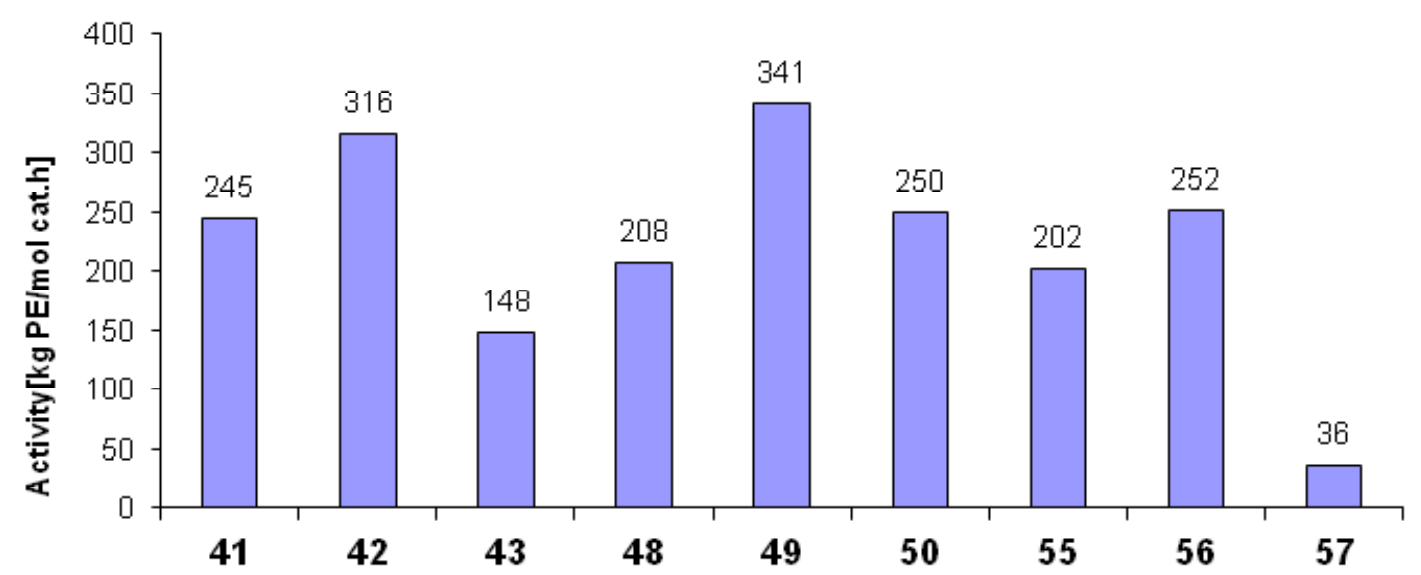

Fig. 8: Effect of bridging unit and substituent type on the activities of bis (benzimidazolyl) titanium complexes 


\section{Elemental analysis}

The elemental analysis data of the synthesized ligands and their complexes are given in (Table 1). The data shows the formation of metal complexes in a 1: 1 (M: L) molar ratio.

\section{Polymerization results}

All coordination compounds were activated with MAO according to the mechanism proposed for the activation of metallocene ${ }^{42,43}$ and 2,6-bis(imino) pyridine iron (II) ${ }^{44}$ catalyst precursors.

The complexes of titanium with ligands derived from bis (benzoimidazolyl), bis (benzoxazolyl)

Table 2: Polymerization activities of complexes 32-62

\begin{tabular}{cc}
\hline No. & Activity $[\mathbf{k g} / \mathbf{m o l}$ cat. h] \\
\hline 32 & 140 \\
33 & 185 \\
34 & 261 \\
35 & 209 \\
36 & 526 \\
37 & 279 \\
38 & 472 \\
39 & 573 \\
40 & 374 \\
41 & 245 \\
42 & 316 \\
43 & 148 \\
44 & 155 \\
45 & 239 \\
46 & 386 \\
47 & 205 \\
48 & 208 \\
49 & 341 \\
50 & 250 \\
51 & 210 \\
52 & 355 \\
53 & 402 \\
54 & 110 \\
55 & 202 \\
56 & 252 \\
57 & 36 \\
58 & 260 \\
59 & 176 \\
60 & 204 \\
61 & 315 \\
62 & 88 \\
\hline &
\end{tabular}

and bis (benzothiazolyl) compounds showed variable activities for ethylene polymerization (Table 2).

The activities are greatly influenced by the hetero atoms in addition to the ligand environment.

2,2-bis (benzimidazolyl), 1,1-Bis (benzimidazolyl) methane, 1,2-bis(benzimidazolyl) ethane and 1,2-bis(benzimidazolyl) benzene titanium complexes act as catalysts for ethylene polymerization, after activation with methylaluminoxane (MAO). They showed variable activities under different polymerization conditions.

The titanium complexes generally show moderate to good activities compared to the benchmark complexes zirconocene $\left(\mathrm{Cp}_{2} \mathrm{ZrCl}_{2}\right)$.

The titanium complexes derived from the ligand systems 2, 2-bis (benzothiazolyl 32, benzoxazolyl $(33,34)$ and benzimidazolyl $(35$, 36) (Figure 7) shows the following activity order 35 / MAO > 33 / MAO > 32 / MAO. The methyl substituted complexes $\mathbf{3 4}$ and $\mathbf{3 6}$ show higher activities compared to the unsubstituted complexes 33 and 35. The different behaviours most probably occur due to the structure of the ligands in which the steric bulk and the electronic state greatly influence the activities of the complexes.

Among the titanium complexes with 1, 1-bis (benzimidazolyl) methane ligands, the activities of the systems decrease in the order 41/MAO > 42/ MAO > 43/MAO (see Figure 8). This result is in contrast to the fact that complexes with both large steric bulk and high electron withdrawing effect will have the highest activities. Complex $\mathbf{4 3}$ with a chlorosubstituent in meta position to the imino nitrogen atoms shows a reduced activity, while complex $\mathbf{4 2}$ with a methyl group in the same position shows a somewhat higher activity. One explanation could be the fact that chlorine as a Lewis base can block the active sites of a neighbouring catalyst molecule.

The unsubstituted complex $\mathbf{4 1}$ shows the highest activity. The same trend is observed for the titanium complexes of 1, 2-bis (benzimidazolyl) benzene: 55/MAO > 56/MAO > 57/MAO. 


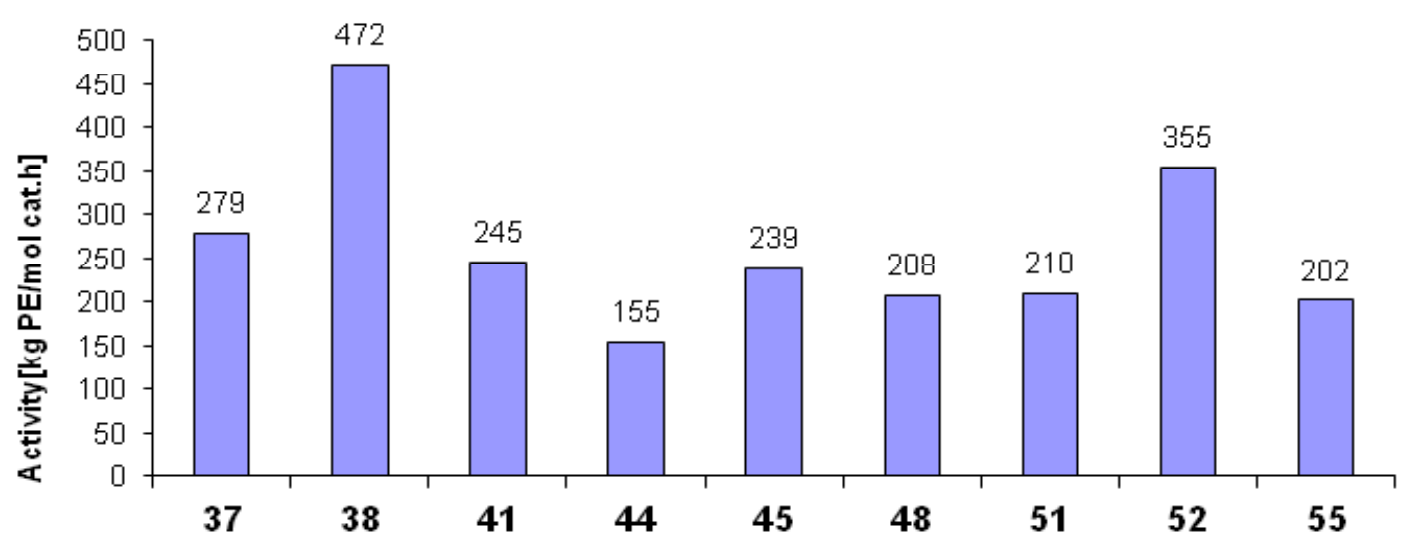

Fig. 9: Activities of benzothiazolyl $(37,44,51)$, benzoxazolyl $(38,45,52)$ and benzimidazolyl $(41,48$, 55) titanium complexes

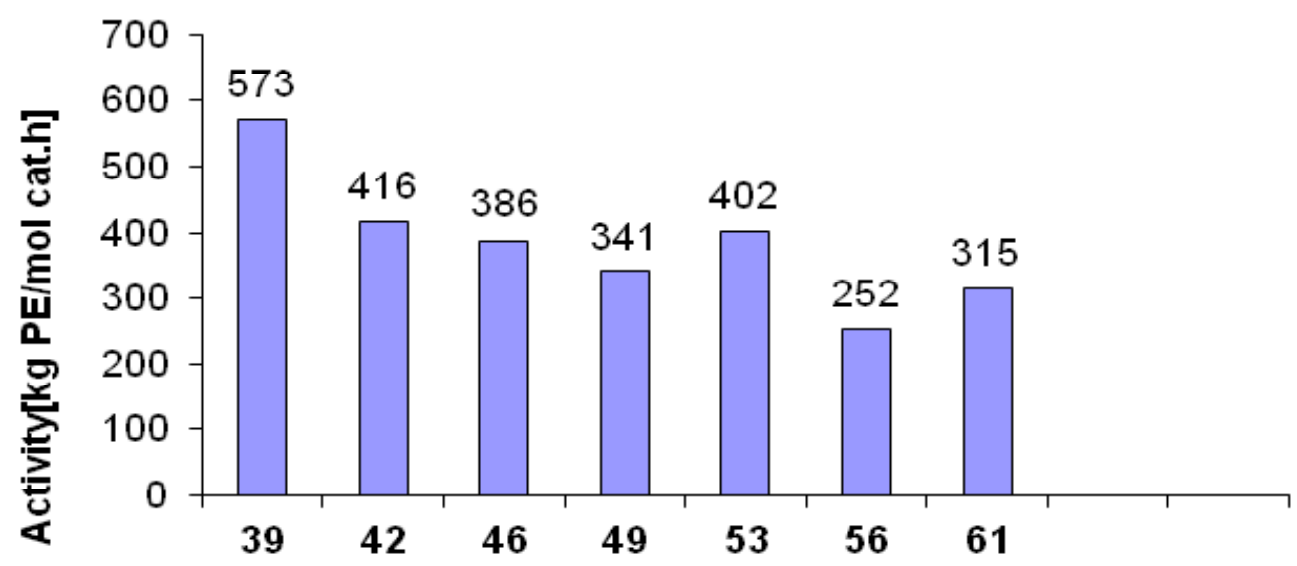

Fig. 10: Effect of methyl substituent on the activities of benzoxazole $(39,46,53)$ and benzimidazole $(42,49,56,61)$

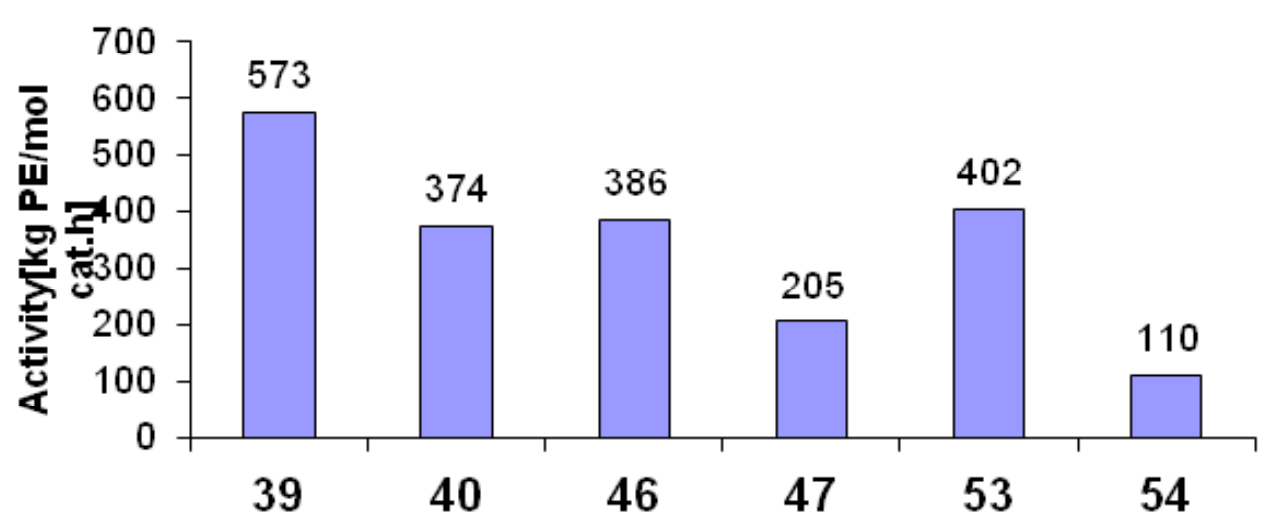

Fig. 11: Effect of substituent position on the activities of benzoxazolyl titanium complexes 
For the titanium complexes derived from 1 , 2-bis (benzimidazolyl) ethane, the activities decrease in the following order: 49/MAO > 50/MAO > 48/MAO (Figure 8).

Ethylene polymerization reactions with complexes of titanium with the ligand systems 1,1bis(benzothiazolyl)methane, 1,2-bis(benzothiazolyl) ethane, and 1,2-bis(benzothiazolyl)benzene. The activities of titanium complexes decrease in the order of 1, 1-bis (benzothiazolyl)methane (37) $>$ 1,2-bis(benzothiazolyl)benzene $(51)>1,2-$ bis(benzothiazolyl) ethane (44) (Figure 9). This order of activity can be accounted for by structural variations of the ligand systems.

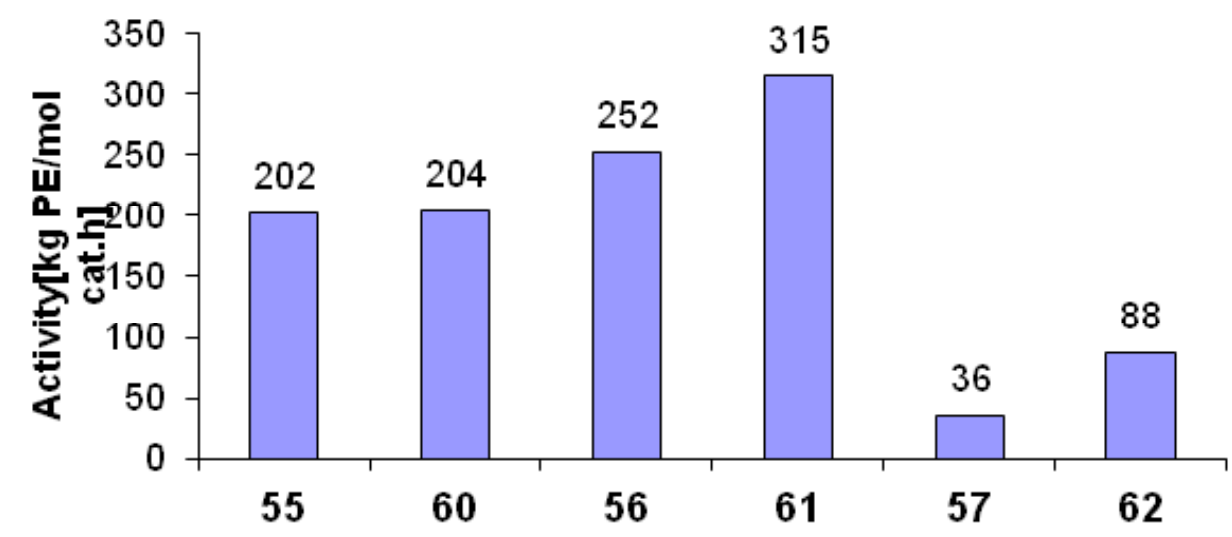

Fig. 12: Effect of substituent type on the activities of bis (benzimidazolyl) benzene titanium complexes

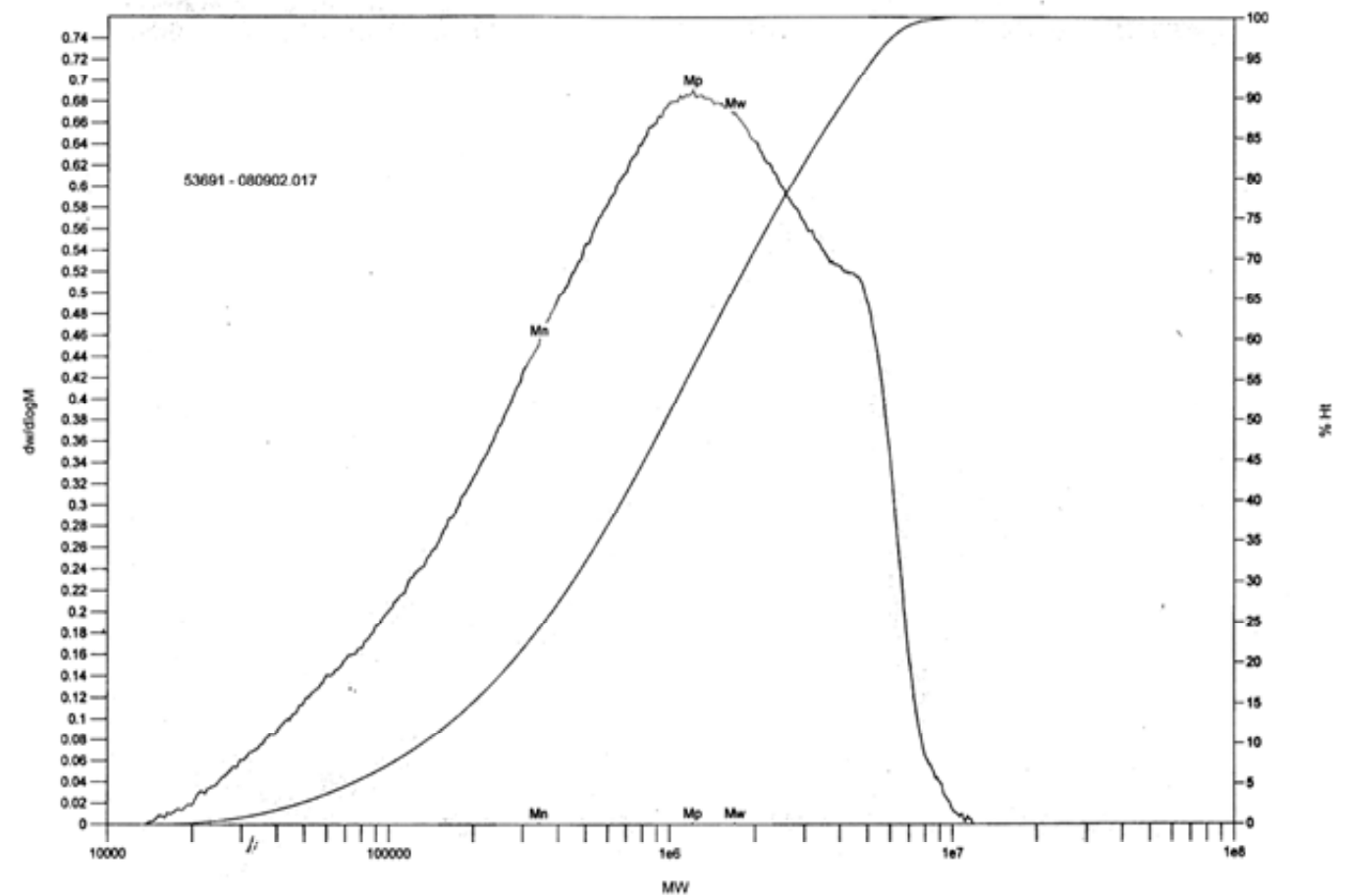

Fig. 13: GPC profile for polyethylene produced with catalyst 55 / MAO 


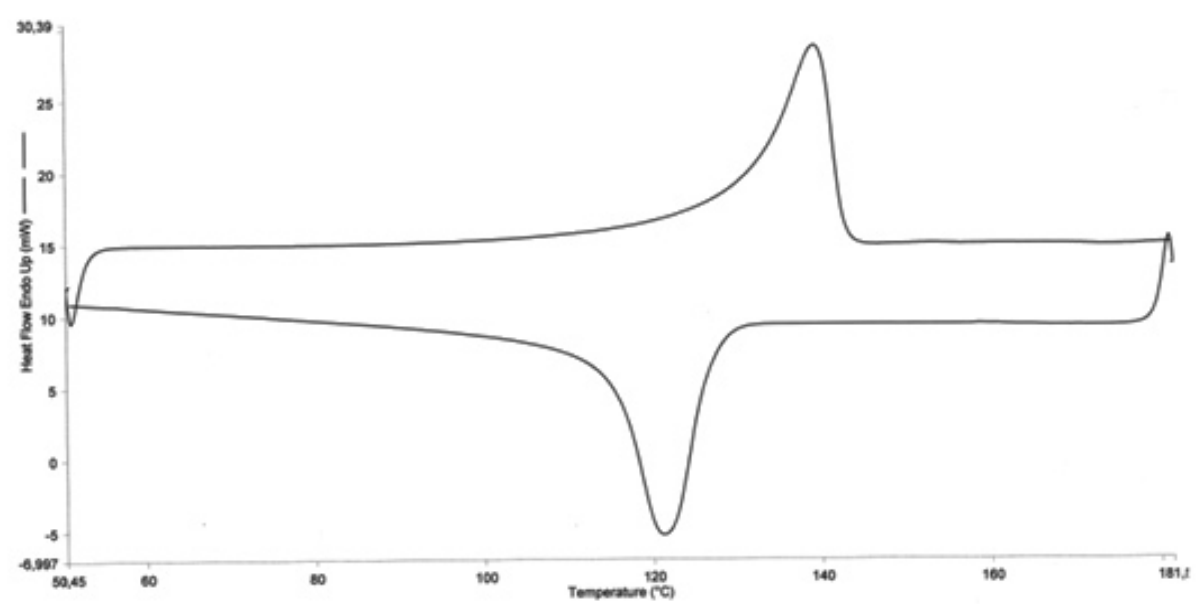

Fig. 14: DSC curve for the polyethylene produced with the catalyst 55 / MAO

The activity of unsubstituted (benzothiazolyl, benzoxazolyl and benzimidazolyl) titanium complexes (Figure9) shows great dependence on both heteroatom and bridging units. For example the complexes derived from the ligand systems bis(benzothiazolyl) shows the following order 1, 1-bis(benzothiazolyl) methane $37>1$, 2- bis(benzothiazolyl) benzene $51>1,2$-bis(benzothiazolyl) ethane 44 . The bis(benzoxazolyl, benzimidazolyl) derived titanium complexes shows the same activity order 1, 1-bis(benzoxazolyl) methane $38>1,2-$ bis(benzoxazolyl) ethane $45>1$, 2-bis (benzoxazolyl) benzene 52. 1, 1-bis (benzimidazolyl) methane $\mathbf{4 1}$ $>1$, 2- bis (benzimidazolyl) ethane $48>1$, 2-bis (benzimidazolyl) benzene $\mathbf{5 5}$. The similar activity order of $\mathrm{O}, \mathrm{N}$ containing ligands can be attributed to the similarities between the two hetero atoms. The 1,1-bis(benzoxazolyl) methane complex $\mathbf{3 8}$ shows a higher activity than the 1,2-bis(benzoxazolyl) benzene complex $\mathbf{5 2}$ and the 1,2-bis(benzoxazolyl) ethane complex 45 . They show higher activities than those obtained from the benzothiazole ligand of the same type (Figure 9). This is most probably due to extra stabilization of the active species caused by the strong electronegative oxygen atom leading to an increase in electrophilicity of the metal center.

The methyl substituted bis-(benzoxazolyl, and benzimidazolyl) titanium complexes (Figure 10)

Shows that, the bis benzoxazolyl complexes were more active than the bis benzimidazolyl complexes, for example the catalyst system 39 / MAO shows an activity of $573[\mathrm{~kg} / \mathrm{mol}$ cat. h] while the catalyst derived from 1,1 , bis(benzimidazolyl) methane 42 / MAO shows an activity of $416[\mathrm{~kg} / \mathrm{mol}$ cat. h].

The methyl substituted bis-benzoxazole titanium complexes (Figure 11) behave differently depending on the position of the methyl group at the phenyl ring of the benzoxazolyl moiety. When the methyl group is introduced in the meta-position to the imino-nitrogen atom $(39,46,53)$ it leads to an increase of the activity due to both electronic and steric effects. On the other hand, when the methyl group is introduced in the para position $(\mathbf{4 0}, \mathbf{4 7}, \mathbf{5 4})$ with respect to the imino nitrogen atom, the activities drop because the electron density on the nitrogen atom increases and consequently the nucleophilicity of the central metal atom increases which weakens the interaction between the metal atom and the p-electrons of the ethylene monomer and hence this decreases the rate of ethylene insertion in the chain-growth steps ${ }^{27,45}$.

The activities of bis (benzimidazolyl) benzene titanium complexes $(55,56$, and 57$)$ and bis (benzimidazolyl) - 4-methyl benzene titanium complexes $(60,61$, and 62$)$ (Figure 11) revealed that the chloro substituted complexes are more active than the methyl substituted complexes. However both chloro and methyl substituted complexes of bis (benzimidazolyl) benzene $(56,57)$ are much more 
Table 3: 1H NMR, 13C NMR and mass spectroscopic data of ligand precursors and complexes

\begin{tabular}{|c|c|c|c|}
\hline No & $\begin{array}{l}{ }^{1} \mathrm{H} \text { NMR } \\
\delta[\text { ppm] }\end{array}$ & $\begin{array}{l}{ }^{13} \text { C NMR } \\
\delta \text { [ppm] }\end{array}$ & Mass $\mathrm{m} / \mathrm{z}(\%)$ \\
\hline 1 & $\begin{array}{l}\text { 8.15(d,2H), 7.96(d,2H), } \\
7.54(\mathrm{t}, 2 \mathrm{H}), 7.47(\mathrm{t}, 2 \mathrm{H})\end{array}$ & n.d. & $268 \mathrm{M}^{\circ}+(100)$ \\
\hline 2 & $\begin{array}{l}\text { 7.93(d,2H), 7.73(d,2H), } \\
7.51(t, 4 \mathrm{H})\end{array}$ & $\begin{array}{l}152.1,151.2,141.4 \\
127.8,126.0,121.8 \\
111.7\end{array}$ & $236 \mathrm{M}^{\circ}+(100)$ \\
\hline 3 & $\begin{array}{l}7.63(\mathrm{~s}, 2 \mathrm{H}), 7.11(\mathrm{~d}, 2 \mathrm{H}), \\
6.98(\mathrm{~d}, 2 \mathrm{H}) \\
2.37(\mathrm{~s}, 6 \mathrm{H})\end{array}$ & $\begin{array}{l}\text { 155.4, 147.5, 141.3, } \\
\text { 132.7,127.7,123.2, } \\
108.6,20.9\end{array}$ & $264 \mathrm{M}^{\circ}+(100)$ \\
\hline 4 & $\begin{array}{l}12.22(\mathrm{br}, 2 \mathrm{H}, \mathrm{NH}), 7.11- \\
6.99(\mathrm{~m}, 8 \mathrm{H})\end{array}$ & $\begin{array}{l}156.0,126.4 \\
123.8,116.0\end{array}$ & $234 \mathrm{M}^{\circ}+(100)$ \\
\hline 5 & $\begin{array}{l}12.32(\mathrm{br}, 2 \mathrm{H}, \mathrm{NH}), 6.99- \\
6.96(\mathrm{~m}, 2 \mathrm{H}), 6.87- \\
6.84(\mathrm{~m}, 4 \mathrm{H}), 2.23\left(\mathrm{~s}, 6 \mathrm{H}, \mathrm{CH}_{3}\right)\end{array}$ & $\begin{array}{l}156.0,155.6,132.9 \\
126.1,124.4,123.2 \\
115.8,115.6,21.2\end{array}$ & $262 \mathrm{M}^{\circ}+(100)$ \\
\hline 6 & $\begin{array}{l}\text { 8.04(d,2H), 7.95(d,2H), } \\
\text { 7.47(t,2H), 7.43(t,2H), } \\
5.05\left(\mathrm{~s}, 2 \mathrm{H}, \mathrm{CH}_{2}\right)\end{array}$ & $\begin{array}{l}167.0,153.2,135.9 \\
127.0,125.9,123.2 \\
122.9,38.5\end{array}$ & $282 \mathrm{M}^{\circ}+(100)$ \\
\hline 7 & $\begin{array}{l}7.70(\mathrm{~d}, 2 \mathrm{H}), 7.50(\mathrm{~d}, 2 \mathrm{H}) \\
7.31(\mathrm{t}, 4 \mathrm{H}), 4.62\left(\mathrm{~s}, 2 \mathrm{H}, \mathrm{CH}_{2}\right)\end{array}$ & $\begin{array}{l}159.5,151.5,141.3 \\
125.5,124.8,120.4 \\
110.9,29.6\end{array}$ & $250 \mathrm{M}^{\circ}+(100)$ \\
\hline 8 & $\begin{array}{l}7.60(\mathrm{~d}, 2 \mathrm{H}), 7.52(\mathrm{~s}, 2 \mathrm{H}) \\
7.21(\mathrm{~d}, 2 \mathrm{H}), 4.84\left(\mathrm{~s}, 2 \mathrm{H}, \mathrm{CH}_{2}\right), \\
2.41\left(\mathrm{~s}, 6 \mathrm{H}, 2 \mathrm{CH}_{3}\right)\end{array}$ & $\begin{array}{l}161.4,149.5,141.5 \\
134.7,126.9,120.2 \\
110.9,29.4,21.6\end{array}$ & $278 \mathrm{M}^{\circ}+(100)$ \\
\hline 9 & $\begin{array}{l}7.59(\mathrm{~d}, 2 \mathrm{H}), 7.52(\mathrm{~s}, 2 \mathrm{H}) \\
7.19(\mathrm{~d}, 2 \mathrm{H}), 4.82\left(\mathrm{~s}, 2 \mathrm{H}, \mathrm{CH}_{2}\right), \\
2.46\left(\mathrm{~s}, 6 \mathrm{H}, 2 \mathrm{CH}_{3}\right)\end{array}$ & $\begin{array}{l}160.8,151.5,139.2 \\
136.0,126.4,119.7 \\
111.5,29.3,21.9\end{array}$ & $278 \mathrm{M}^{\circ}+(100)$ \\
\hline 10 & $\begin{array}{l}\text { 12.41(s,2H, NH), } \\
7.46(\mathrm{~m}, 4 \mathrm{H}) \\
7.11(\mathrm{~m}, 4 \mathrm{H}), 4.43\left(\mathrm{~s}, 2 \mathrm{H}, \mathrm{CH}_{2}\right)\end{array}$ & $\begin{array}{l}150.8,138.4122 .9 \\
115.4,29.8\end{array}$ & $248 \mathrm{M}^{\circ}+(100)$ \\
\hline 11 & $\begin{array}{l}7.32(\mathrm{~d}, 2 \mathrm{H}), 7.23(\mathrm{~s}, 2 \mathrm{H}) \\
6.91(\mathrm{~d}, 2 \mathrm{H}), 4.35\left(\mathrm{~s}, 2 \mathrm{H}, \mathrm{CH}_{2}\right), \\
2.33\left(\mathrm{~s}, 6 \mathrm{H}, \mathrm{CH}_{3}\right)\end{array}$ & $\begin{array}{l}150.6,139.2137 .9 \\
131.2,123.5,115.3 \\
114.7,30.0,21.9\end{array}$ & $276 \mathrm{M}^{\circ}+(100)$ \\
\hline 12 & $\begin{array}{l}\text { 7.54(s,2H), 7.48(d,2H), } \\
\left.\text { 7.14(d,2H), 4.46(s,2H, } \mathrm{CH}_{2}\right)\end{array}$ & $\begin{array}{l}149.3,134.7,132.5 \\
129.6,125.9,116.6 \\
115.1,26.8\end{array}$ & $317 \mathrm{M}^{\circ}+(100)$ \\
\hline 13 & $\begin{array}{l}7.98(\mathrm{~d}, 2 \mathrm{H}), 7.82(\mathrm{~d}, 2 \mathrm{H}), \\
7.44(\mathrm{t}, 2 \mathrm{H}), 7.37(\mathrm{t}, 2 \mathrm{H}), \\
3.74\left(\mathrm{~s}, 4 \mathrm{H}, 2 \mathrm{CH}_{2}\right)\end{array}$ & $\begin{array}{l}169.6,153.5,135.5 \\
126.4,125.3,123.0 \\
121.9,33.6\end{array}$ & $296 \mathrm{M}^{\circ}+(100)$ \\
\hline 14 & $\begin{array}{l}\text { 7.65(t,2H), 7.46(t,2H), } \\
7.28(\mathrm{~d}, 4 \mathrm{H}), 3.56(\mathrm{~s}, 4 \mathrm{H})\end{array}$ & $\begin{array}{l}165.2,151.2,141.6 \\
125.2,124.7,120.2, \\
110.9,25.7\end{array}$ & $264 \mathrm{M}^{\circ}+(100)$ \\
\hline 15 & $\begin{array}{l}7.46(\mathrm{~s}, 2 \mathrm{H}), 7.41(\mathrm{~d}, 2 \mathrm{H}) \\
7.16(\mathrm{~d}, 2 \mathrm{H}) \\
3.55\left(\mathrm{~s}, 4 \mathrm{H}, 2 \mathrm{CH}_{2}\right) \\
2.47\left(\mathrm{~s}, 6 \mathrm{H}, 2 \mathrm{CH}_{3}\right)\end{array}$ & $\begin{array}{l}165.5,149.4,141.8 \\
134.3,125.9,119.7 \\
109.9,25.7,21.3\end{array}$ & $292 \mathrm{M}^{\circ}+(100)$ \\
\hline
\end{tabular}


16

7.53(d,2H), 7.35(s,2H),

7.16(d,2H),

$3.54\left(\mathrm{~s}, 4 \mathrm{H}, 2 \mathrm{CH}_{2}\right)$,

$2.50\left(\mathrm{~s}, 6 \mathrm{H}, 2 \mathrm{CH}_{3}\right)$

$17 \quad 7.57(\mathrm{~d}, 4 \mathrm{H}), 7.26(\mathrm{t}, 4 \mathrm{H})$,

$3.56\left(\mathrm{~s}, 4 \mathrm{H}, 2 \mathrm{CH}_{2}\right)$

$187.31(\mathrm{~d}, 2 \mathrm{H}), 7.22(\mathrm{~s}, 2 \mathrm{H})$,

$6.90(\mathrm{~d}, 2 \mathrm{H}), 3.51$

$\left(\mathrm{s}, 4 \mathrm{H}, \mathrm{CH}_{2}\right), 2.33\left(\mathrm{~s}, 6 \mathrm{H}, \mathrm{CH}_{3}\right)$

$197.50(\mathrm{~s}, 2 \mathrm{H}), 7.44(\mathrm{~d}, 2 \mathrm{H})$, $7.09(\mathrm{~d}, 2 \mathrm{H}), 3.36$ $\left(\mathrm{s}, 4 \mathrm{H}, 2 \mathrm{CH}_{2}\right)$

20

8.01(d,2H), 7.93-

$7.90(\mathrm{dd}, 2 \mathrm{H}), 7.77(\mathrm{~d}, 2 \mathrm{H})$,

7.61-7.58(dd,2H),

7.44(t,2H), 7.33(t,2H)

21

8.07(t,2H), 7.81(t,2H),

7.72(t,2H), 7.53(d,2H),

7.35(d,4H)

22

8.13(t,2H), 7.84(d,2H)

7.52(s,2H), 7.44(d,2H),

$7.19(\mathrm{~d}, 2 \mathrm{H}), 2.40\left(\mathrm{~s}, 6 \mathrm{H}, 2 \mathrm{CH}_{3}\right)$

23

8.12-8.09(m,2H),

7.85-7.82(m,2H), 7.60(d,2H),

7.37(s,2H), 7.20(d,2H),

$2.41\left(\mathrm{~s}, 6 \mathrm{H}, 2 \mathrm{CH}_{3}\right)$

$247.88(\mathrm{~d}, 1 \mathrm{H}), 7.80(\mathrm{~d}, 1 \mathrm{H})$,

$7.69(\mathrm{t}, 2 \mathrm{H}), 7.64(\mathrm{~s}, 2 \mathrm{H}, \mathrm{N}-\mathrm{H})$,

$7.61(\mathrm{~m}, 4 \mathrm{H}), 7.26(\mathrm{~m}, 4 \mathrm{H})$,

25

8.05(s,2H), 7.78(s,2H,N-H),

$7.63(\mathrm{~s}, 2 \mathrm{H}), 7.56(\mathrm{~d}, 2 \mathrm{H})$,

7.35(s,2H), 7.00(d,2H),

$2.37\left(\mathrm{~s}, 6 \mathrm{H}, \mathrm{CH}_{3}\right)$

26

$8.14(\mathrm{~s}, 2 \mathrm{H}), 7.61(\mathrm{br}, 4 \mathrm{H})$,

$7.55(\mathrm{~d}, 2 \mathrm{H}), 7.12(\mathrm{~d}, 2 \mathrm{H})$

27

8.01-7.95(m,2H), 7.84-

$7.79(\mathrm{~m}, 3 \mathrm{H}), 7.74(\mathrm{~s}, 1 \mathrm{H})$,

7.48-7.44(m,3H), 7.38-

7.33(m,2H), 2.50(s,3H, $\left.\mathrm{CH}_{3}\right)$

28

7.97(d,1H), 7.89(s,1H),

7.64(d,2H), 7.59(d,1H),

7.49(d,2H), 7.31(t,4H),

$2.37\left(\mathrm{~s}, 3 \mathrm{H}, \mathrm{CH}_{3}\right)$
164.8, 151.5, 139.3,

135.4, 125.5, 119.1,

$110.7,25.6,21.6$

153.8, 135.4, 124.3,

$114.6,25.4$

154.2, 138.7, 137.4,

131.2, 123.5, 115.0,

$114.5,27.0,21.9$

156.2, 140.6, 138.0,

126.3, 122.1, 116.2,

115.127 .0

166.4, 153.4, 136.6,

$133.5,131.6,131.5$,

$127.2,126.3,123.8$,

121.9

$162.2,151.0,141.9$,

$132.5,131.7,127.4$,

$126.5,125.5,120.7$,

111.5

162.3, 149.4, 142.2,

$134.9,132.4,131.6$,

127.6, 127.4, 120.5,

$110.9,21.6$

$161.8,151.4,139.8,136.5,340 \mathrm{M}^{\circ}+(100)$

132.3, 131.7, 127.5,

126.7, 120.2, 111.4, 21.9

151.6, 137.9, 133.5,

$131.9,129.4$,

$123.5,115.5$

151.6, 139.0, 137.8,

132.2, 132.0, 130.4,

$129.9,115.9,115.1$,

22.0

154.3, 141.4, 138.9,

132.1, 130.4, 130.3,

126.6, 122.4, 117.1,

115.8

166.6, 166.5, 153.6,

153.5, 141.1, 136.8,

136.8, 133.5, 131.8,

131.2, 131.1, 131.0,

126.3, 126.2, 125.5,

125.4, 123.6, 123.5,

$121.7,121.6,21.3$

162.7, 162.6, 151.2,

151.1, 142.2, 142.1,

142.1, 132.1, 131.9,

131.19, 127.5, 125.5,
$310 \mathrm{M}^{\circ}+(100)$

$338 \mathrm{M}^{\circ}+(100)$

$292 \mathrm{M}^{\circ}+(100)$

$262 \mathrm{M}^{\circ}+(100)$

$290 \mathrm{M}^{\circ}+(100)$

$331 \mathrm{M}^{\circ}+(100)$

$344 \mathrm{M}^{\circ}+(100)$

$312 \mathrm{M}^{\circ}+(100)$

$340 \mathrm{M}^{\circ}+(100)$

$378 \mathrm{M}^{\circ}+(100)$

$358 \mathrm{M}^{\circ}+(100)$

$326 \mathrm{M}^{\circ}+(100)$ 
29

9.67(s,2H,N-H), 7.97(d,1H), 7.92(s,1H), 7.56-7.51(m,4H), 7.48-7.46(d,1H), 7,187.15(m,4H), 2.40(s;3H, $\left.\mathrm{CH}_{2}\right)$

$30 \quad 7.96(\mathrm{~d}, 1 \mathrm{H}), 7.91(\mathrm{~s}, 1 \mathrm{H}), 7.44-$ $7.43(\mathrm{~m}, 3 \mathrm{H}), 7.35(\mathrm{~s}, 2 \mathrm{H})$, 6.98(d,2H), 2.42(s,3H, $\left.\mathrm{CH}_{3}\right)$, $2.36\left(\mathrm{~s}, 6 \mathrm{H}, 2 \mathrm{CH}_{3}\right)$

$318.09(\mathrm{~d}, 1 \mathrm{H}), 8.04(\mathrm{~s}, 1 \mathrm{H})$, $7.62(\mathrm{~d}, 2 \mathrm{H}), 7.56-$

$7.53(\mathrm{~m}, 2 \mathrm{H}), 7.36(\mathrm{~d}, 1 \mathrm{H})$, $7.10(\mathrm{~d}, 2 \mathrm{H}), 2.38\left(\mathrm{~s}, 3 \mathrm{H}, \mathrm{CH}_{3}\right)$

$328.23(\mathrm{~d}, 2 \mathrm{H}), 7.97(\mathrm{~d}, 2 \mathrm{H})$, $7.56(\mathrm{t}, 2 \mathrm{H}), 7.50(\mathrm{t}, 2 \mathrm{H})$

$33 \quad 7.95(\mathrm{dd}, 4 \mathrm{H}), 7.60-$ $7.56(\mathrm{~m}, 4 \mathrm{H})$

$347.66(\mathrm{~s}, 2 \mathrm{H}), 7.20(\mathrm{~d}, 2 \mathrm{H})$, $7.00(\mathrm{~d}, 2 \mathrm{H})$ 2.39(s,6H)

$3512.50(\mathrm{br}, 2 \mathrm{H}, \mathrm{NH})$, $7.40(\mathrm{~d}, 4 \mathrm{H}), 7.15(\mathrm{t}, 4 \mathrm{H})$

$36 \quad 12.12(\mathrm{br}, 2 \mathrm{H}, \mathrm{NH})$, 7.06(d,2H), 6.97(s,2H), $6.82(\mathrm{~d}, 2 \mathrm{H}), 2.17(\mathrm{~s}, 6 \mathrm{H}$, $\left.2 \mathrm{CH}_{3}\right)$
$125.4,124.9,124.6$, $124.5,120.4,120.2$, $110.7,110.6,21.4$ 152.1,152.0,140.3, 132.6, 132.5, 131.1, 131.0 129.9, 127.3, 122.8, 122.7, 115.2, 21.5

151.7,151.6,140.1, 132.5, 132.2, 132.1, 132.0, 131.0, 129.7, 127.2, 124.3, 124.2, 116.3, 115.5, 22.0,

21.4

155.0,155.1, 141.7,141.6, 139.2,139.1, 132.5,132.1, 130.8,130.3, 127.6,126.3,126.2 122.2,122.1 117.0,116.9, 115.7,115.6, 21.4 n.d. $324 \mathrm{M}^{\circ}+(100)$ $352 \mathrm{M}^{\circ}+(100)$ $393 \mathrm{M}^{\circ}+(100)$ $458 \mathrm{M}^{\circ}(20), 422$ $\mathrm{M}^{\circ}+\mathrm{Cl}$ (10), 387 $\mathrm{M}^{\circ}+2 \mathrm{Cl}$ (20), 317 $\mathrm{M}^{\circ}+4 \mathrm{Cl}(20), 268$ $\mathrm{M}^{\circ}+\mathrm{TiCl}_{4}(100)$

152.3, 150.9, 141.3, $128.5,126.7,121.8$, 112.4

$425 \mathrm{M}^{\circ}+(30), 390$ $\mathrm{M}^{\circ}+\mathrm{Cl}(25), 321$ $\mathrm{M}^{\circ}+3 \mathrm{Cl}(10), 284$ $\mathrm{M}^{\circ}+4 \mathrm{Cl}$ (20), 236 $\mathrm{M}^{\circ}+\mathrm{TiCl}_{4}(100)$

155.2, 147.7, 141.5, 132.6,127.5,123.0, 109.1, 21.1

$454 \mathrm{M}^{\circ}+(20), 418$ $\mathrm{M}^{\circ}+\mathrm{Cl}(10), 383$ $\mathrm{M}^{\circ}+2 \mathrm{Cl}(10), 314$ $\mathrm{M}^{\circ}+4 \mathrm{Cl}(20), 264$

156.1, 126.6, 123.8, 116.2

$\mathrm{M}^{\circ}+\mathrm{TiCl}_{4}(100)$ $424^{\circ}+(20), 352$ $\mathrm{M}^{\circ}+2 \mathrm{Cl}(20), 317$ $\mathrm{M}^{\circ}+3 \mathrm{Cl}(10), 234$ $\mathrm{M}^{\circ}+\mathrm{TiCl}_{4}(100)$

156.1, 155.8, 133.0, 126.2, 124.6, 124.1, 115.9, 115.7, 21.3
$495 \mathrm{M}^{\circ}+(10), 478$ $\mathrm{M}^{\circ}+\mathrm{CH}_{3}(15), 423$ $\mathrm{M}^{\circ}+2 \mathrm{Cl}$ (20), 389 $\mathrm{M}^{\circ}+3 \mathrm{Cl}$ (20), 352 $\mathrm{M}^{\circ}+4 \mathrm{Cl}(20) 262$ $\mathrm{M}^{\circ}+\mathrm{ZrCl}_{4}(50)$ 


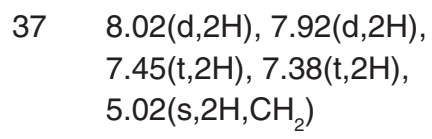

$7.61(\mathrm{~d}, 2 \mathrm{H}), 7.53(\mathrm{~s}, 2 \mathrm{H})$, 7.23(d,2H), 4.84(s,2H, $\left.\mathrm{CH}_{2}\right)$, $2.41\left(\mathrm{~s}, 6 \mathrm{H}, 2 \mathrm{CH}_{3}\right)$

40

7.60(d,2H), 7.54(s,2H), $7.21(\mathrm{~d}, 2 \mathrm{H}), 4.82\left(\mathrm{~s}, 2 \mathrm{H}, \mathrm{CH}_{2}\right)$, $2.44\left(\mathrm{~s}, 6 \mathrm{H}, 2 \mathrm{CH}_{3}\right)$

$41 \quad 7.52-7.49(\mathrm{~m}, 4 \mathrm{H}), 7.52-$ $7.14(\mathrm{~m}, 4 \mathrm{H}), 4.55\left(\mathrm{~s}, 2 \mathrm{H}, \mathrm{CH}_{2}\right)$

42

7.63(d,2H), 7.54(s,2H), 7.31(d,2H), 5.25(s,2H, $\left.\mathrm{CH}_{2}\right)$, 2.42(s, $\left.6 \mathrm{H}, 2 \mathrm{CH}_{3}\right)$

43

7.88(s,2H), 7.80(d,2H), $7.51(\mathrm{~d}, 2 \mathrm{H}), 5.18\left(\mathrm{~s}, 2 \mathrm{H}, \mathrm{CH}_{2}\right)$

44

8.02(d,2H), 7.99(d,2H),

7.44-7.35(m,4H), $3.68\left(\mathrm{~s}, 4 \mathrm{H}, 2 \mathrm{CH}_{2}\right)$

$457.59(\mathrm{t}, 2 \mathrm{H}), 7.26(\mathrm{t}, 2 \mathrm{H})$, 7.16(d,2H), 7.09(d,2H), $3.47\left(\mathrm{~s}, 4 \mathrm{H}, 2 \mathrm{CH}_{2}\right)$

46

7.53(s,2H), 7.48(d,2H), 7.24(d,2H), $3.76\left(\mathrm{~s}, 4 \mathrm{H}, 2 \mathrm{CH}_{2}\right)$, 2.39(s, $\left.6 \mathrm{H}, 2 \mathrm{CH}_{3}\right)$
167.0, 153.2, 135.8, 127.0, 125.9, 123.2, $122.9,38.4$

161.4, 151.2, 141.3, 126.1, 125.4, 120.4, $111.5,29.3$

161.5, 149.4, 141.5, 134.8, 127.0, 120.2, 111.0, 29.4, 21.7

160.8, 151.5, 139.1, 136.1, 126.5, 119.8, $111.5,29.3,21.9$

149.0, 135.4, 124.4, $115.1,27.5$

146.3, 136.3, 132.3, 130.1, 127.8, 114.3, $114.1,25.8,21.8$

149.3, 134.7, 132.6, $129.8,125.9,116.5$, $114.9,26.9$

170.6, 153.3, 135.3, 126.9, 125.8, 123.1, $122.9,33.1$

166.1, 150.9, 141.4, $125.5,124.9,112.0$, $111.2,25.3$

167.2, 149.7, 142.3, 136.0, 127.6, 119.5, 111.2, 25.6, 21.4

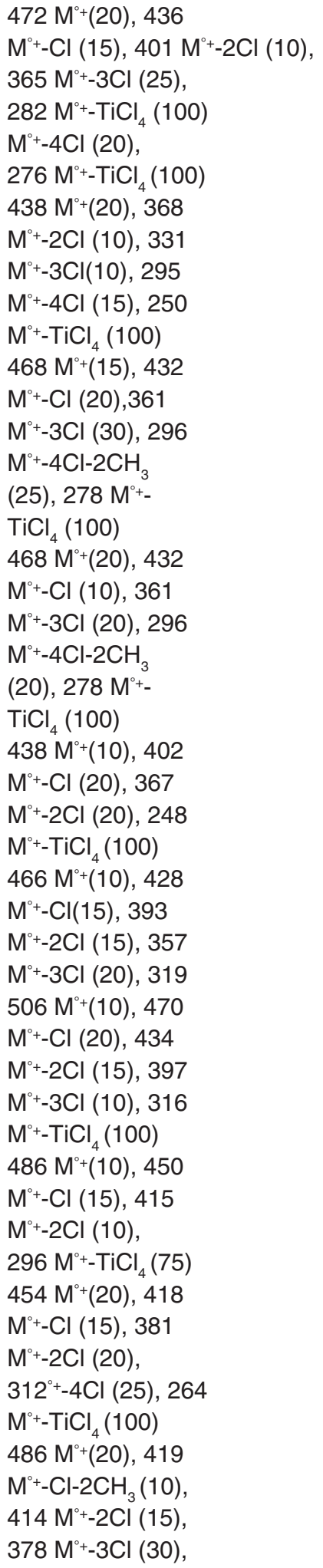


$7.14(\mathrm{~d}, 2 \mathrm{H})$,

$3.49\left(\mathrm{~s}, 4 \mathrm{H}, 2 \mathrm{CH}_{2}\right)$,

7.44(t,2H)

$48 \quad 7.76-7.70(\mathrm{~m}, 4 \mathrm{H}), 7.50-$

$7.43(\mathrm{~m}, 4 \mathrm{H})$,

$3.95\left(\mathrm{~s}, 4 \mathrm{H}, 2 \mathrm{CH}_{2}\right)$

49

50

7.84(s,2H), 7.78(d,2H), $7.50(\mathrm{~d}, 2 \mathrm{H}), 3.78\left(\mathrm{~s}, 4 \mathrm{H}, 2 \mathrm{CH}_{2}\right)$ $2.42\left(\mathrm{~s}, 6 \mathrm{H}, 2 \mathrm{CH}_{3}\right)$
7.52(s,2H), 7.49(d,2H),

165.5, 151.2, 139.3, 135.4, 126.0, 119.4, $111.3,25.3,21.9$ 123.0

152.5, 132.6, 125.6, 114.6, 24.5

151.1, 136.3, 133.0, 130.0, 126.7, 114.7, $114.4,24.7,21.9$

154.3, 135.5, 133.6, 130.3, 125.0, 116.2, $115.0,25.7$

166.4, 153.4, 136.6, 133.5, 131.7, 131.6, 127.3, 126.4, 123.8, 162.2, 151.0, 141.9, $132.5,131.7,127.4$, 126.5, 125.5, 120.7, 111.5

$53 \quad 8.12(\mathrm{~d}, 2 \mathrm{H}), 7.85(\mathrm{t}, 2 \mathrm{H})$, 7.53(s,2H), 7.46(d,2H), $7.21(\mathrm{~d}, 2 \mathrm{H}), 2.42\left(\mathrm{~s}, 6 \mathrm{H}, 2 \mathrm{CH}_{3}\right)$

54
161.8, 151.4, 139.8, 136.6, 132.4, 131.7, $127.5,126.7,120.2$ 111.5, 21.9
$296 \mathrm{M}^{\circ}+-\mathrm{TiCl}_{4}$

(100)

$486 \mathrm{M}^{\circ}+(20), 449$

$\mathrm{M}^{\circ}+\mathrm{Cl}(15) 421$

$\mathrm{M}^{\circ}+\mathrm{Cl}-2 \mathrm{CH}_{3}(15)$,

$\mathrm{M}^{\circ}+3 \mathrm{Cl}(10), 344$

$\mathrm{M}^{\circ}+\mathrm{TiCl}_{4}(100)$

$452 \mathrm{M}^{\circ}+(10)$,

$416 \mathrm{M}^{\circ}+\mathrm{Cl}(20)$,

$380 \mathrm{M}^{\circ}+2 \mathrm{Cl}(15)$,

$343 \mathrm{M}^{\circ}+3 \mathrm{Cl}(10)$,

$310 \mathrm{M}^{\circ}+4 \mathrm{Cl}(20)$,

$262 \mathrm{M}^{\circ}+-\mathrm{TiCl}_{4}(10)$

$480 \mathrm{M}^{\circ}+(20), 443$

$\mathrm{M}^{\circ}+\mathrm{Cl}(20), 408$

$\mathrm{M}^{\circ}+2 \mathrm{Cl} 1(5), 372$

$\mathrm{M}^{\circ}+3 \mathrm{Cl}(15), 336$

$\mathrm{M}^{\circ}+4 \mathrm{Cl}$ (20), 290

$\mathrm{M}^{\circ}+\mathrm{TiCl}_{4}(100)$

$518 \mathrm{M}^{\circ}+(10), 485$

$\mathrm{M}^{\circ}+\mathrm{Cl}(15), 450$

$\mathrm{M}^{\circ}+2 \mathrm{Cl}(10), 413$

$\mathrm{M}^{\circ}+-3 \mathrm{Cl}(10), 377$

$\mathrm{M}^{\circ}+4 \mathrm{Cl}$ (20) 330

$\mathrm{M}^{\circ}{ }^{+}-\mathrm{TiCl}_{4}(100)$

$414 \mathrm{M}^{\circ}+-2 \mathrm{Cl}(20)$,

$378 \mathrm{M}^{\circ}+3 \mathrm{Cl}(20), 296$

$\mathrm{M}^{\circ}+-\mathrm{TiCl}_{4}(100)$

$534 \mathrm{M}^{\circ}+(10), 498$

$\mathrm{M}^{\circ}+\mathrm{Cl}(20), 463$

$\mathrm{M}^{\circ}+-2 \mathrm{Cl}(20), 427$

$545 \mathrm{M}^{\circ}+(10)$,

$509 \mathrm{M}^{\circ}+\mathrm{Cl}(20)$,

$472 \mathrm{M}^{\circ}+-2 \mathrm{Cl}(15)$,

$312 \mathrm{M}^{\circ}+-\mathrm{ZrCl}_{4}$

(100)

$530 \mathrm{M}^{\circ}+(10)$,

$464 \mathrm{M}^{\circ}+\mathrm{Cl}-2 \mathrm{CH}_{3}$

(20),

$459 \mathrm{M}^{\circ}+-2 \mathrm{Cl}(15)$,

$423 \mathrm{M}^{\circ}+-3 \mathrm{Cl}(15)$,

$388 \mathrm{M}^{\circ}+4 \mathrm{Cl}(10)$,

$340 \mathrm{M}^{\circ}+\mathrm{TiCl}_{4}$

(100)

$530 \mathrm{M}^{\circ}+(15)$,

$494 \mathrm{M}^{\circ}+\mathrm{Cl}(20)$,

$430 \mathrm{M}^{\circ}+-2 \mathrm{Cl}-2 \mathrm{CH}_{3}(15)$,

$423 \mathrm{M}^{\circ}+-3 \mathrm{Cl}(10)$,

$389 \mathrm{M}^{\circ}+4 \mathrm{Cl}(20)$,

$340 \mathrm{M}^{\circ}+-\mathrm{TiCl}_{4}(100)$ 
148.2, 134.0, 133.8, 133.6, 126.5, 125.1, 115.4

8.18-8.16(dd,2H), 7.92$7.90(\mathrm{dd}, 2 \mathrm{H})$

7.54(d,2H), 7.44(s,2H), 7.24(d,2H), $2.40\left(\mathrm{~s}, 6 \mathrm{H}, 2 \mathrm{CH}_{3}\right)$

8.22(d,2H), 7.92(t,2H), 7.74(s,2H), 7.69(d,2H), $7.43(\mathrm{~d}, 2 \mathrm{H})$

$58 \quad 8.02(\mathrm{t}, 2 \mathrm{H}), 7.92(\mathrm{t}, 2 \mathrm{H})$, 7.82(d,1H), 7.73(s,1H), 7.53(d,1H), 7.49-7.43(dd,2H), 7.41-7.35(dd,2H), $2.47\left(\mathrm{~s}, 3 \mathrm{H}, \mathrm{CH}_{3}\right)-$

59 7.98(d,1H), 7.91(s,1H), 7.68$7.64(\mathrm{~m}, 2 \mathrm{H}), 7.61(\mathrm{~d}, 1 \mathrm{H})$, 7.53-7.49(dd,2H), 7.32(t,4H), 2,45(s,3H, $\left.\mathrm{CH}_{3}\right)$

8.13(d,1H), 7.70$7.67(\mathrm{~m}, 4 \mathrm{H}), 7.45-$ 7.44(m,6H), 2.51(s,3H, $\left.\mathrm{CH}_{3}\right)$

$61 \quad 8.27(\mathrm{~d}, 2 \mathrm{H}), 7.92(\mathrm{~d}, 1 \mathrm{H})$, 7.74(d,2H), 7.63(s,2H), 7.45(d,2H), 2.65(s,6, $\left.2 \mathrm{CH}_{3}\right)$, 2.61 (s,3H, $\left.\mathrm{CH}_{3}\right)$

$62 \quad 8.06(\mathrm{~s}, 1 \mathrm{H}), 8.04(\mathrm{~s}, 2 \mathrm{H}) 7.70-$ $7.61(\mathrm{~m}, 4 \mathrm{H}), 7.39-$ $7.34(\mathrm{~m}, 2 \mathrm{H}), 2.45\left(\mathrm{~s}, 3 \mathrm{H}, \mathrm{CH}_{3}\right)$
147.7, 137.6, 133.2, $131.9,129.6,128.9$, 127.6, 126.1, 114.8, $114.5,21.8$

151.0, 136.6, 134.5, 132.4, 132.1, 129.3, 126.6, 125.3, 116.8, 115.1

166.5, 166.4, 153.4, 153.4, 141.6, 136.6, $136.5,133.5,132.1,132.0,496 \mathrm{M}^{\circ}+-\mathrm{Cl}-\mathrm{CH}_{3}(15)$, $131.6,130.8,127.1,127.2,441 \mathrm{M}^{\circ}+3 \mathrm{Cl}(20)$, $126.3,126.2,123.8,123.7,405 \mathrm{M}^{\circ}+4 \mathrm{Cl}(20)$, $122.9,122.8,21.5$ 162.3, 162.3, 151.0, $150.9,142.8,141.9$, $141.8,133.0,132.1$, 131.6, 127.3, 126.4, 126.3, 125.5, 125.4, $124.6,120.7,120.6$, $111.5,111.4,21.5$ 149.2, 143.1, 135.1, 134.5, 133.1, 132.7, 126.0, 125.5, 125.3, 122.9, 115.3, 115.2, 21.6

147.0, 146.9, 144.3, 136.6, 136.5, 134.7, 134.1, 133.6, 133.5, 131.6, 131.4, 129.9, 129.2, 128.1, 126.3, 124.2, 121.5, 114.8, 114.7, 114.5, 22.1, 21.9

151.2, 142.7, 137.0, 136.3, 134.8, 134.1, 132.7, 132.5, 132.1, 132.1, 126.8, 125.9, 125.3, 125.1, 123.5, 116.7, 116.6, 115.2, $115.0,21.5$
$500 \mathrm{M}^{\circ}+(10), 463$

$\mathrm{M}^{\circ}+\mathrm{Cl}(20), 428$

$\mathrm{M}^{\circ}+2 \mathrm{Cl}$ (15), 394

$\mathrm{M}^{\circ}+-3 \mathrm{Cl}$ (15), 357

$\mathrm{M}^{\circ}+4 \mathrm{Cl}(20), 310$

$\mathrm{M}^{\circ}+\mathrm{TiCl}_{4}(100)$

$530 \mathrm{M}^{\circ}+(20), 492$

$\mathrm{M}^{\circ}+\mathrm{Cl}(10), 454$

$\mathrm{M}^{\circ}+2 \mathrm{Cl}(15), 418$

$\mathrm{M}^{\circ}+3 \mathrm{Cl}(20), 338$

$\mathrm{M}^{\circ}+\mathrm{TiCl}_{4}(50)$

$568 \mathrm{M}^{\circ}+(10), 481$

$\mathrm{M}^{\circ}+-2 \mathrm{Cl}-\mathrm{NH}(20)$,

$462 \mathrm{M}^{\circ}+3 \mathrm{Cl}(10)$, $426 \mathrm{M}^{\circ}+4 \mathrm{Cl}(20)$, $378 \mathrm{M}^{\circ}+{ }_{-} \mathrm{TiCl}_{4}$

(100)

$548 \mathrm{M}^{\circ}+(10), 512$ $\mathrm{M}^{\circ}+\mathrm{Cl}(20)$, $496 \mathrm{M}^{\circ}+-\mathrm{Cl}-\mathrm{CH}_{3}(15)$
$441 \mathrm{M}^{\circ}+-3 \mathrm{Cl}(20)$,
$405 \mathrm{M}^{\circ}+-4 \mathrm{Cl}(20)$,
$358 \mathrm{M}^{\circ}+-\mathrm{TiCl}_{4}(100)$ $516 \mathrm{M}^{\circ}+(10)$, $480 \mathrm{M}^{\circ}+\mathrm{Cl}(10)$, $444 \mathrm{M}^{\circ}+2 \mathrm{Cl}(20)$, $408 \mathrm{M}^{\circ}-2 \mathrm{Cl}(10)$, $372 \mathrm{M}^{\circ}+4 \mathrm{Cl}(20)$, $326 \mathrm{M}^{\circ}+\mathrm{TiCl}_{4}$ (100) $516 \mathrm{M}^{\circ}+(20), 443$ $\mathrm{M}^{\circ}+-2 \mathrm{Cl}$ (20), 409 $\mathrm{M}^{\circ}+3 \mathrm{Cl}$ (20), 372 $\mathrm{M}^{\circ}+-4 \mathrm{Cl}$ (20), 324 $\mathrm{M}^{\circ}+\mathrm{TiCl}_{4}(50)$ $542 \mathrm{M}^{\circ}+(20), 468$ $\mathrm{M}^{\circ}+2 \mathrm{Cl}(20), 433$ $\mathrm{M}^{\circ}+3 \mathrm{Cl}$ (15), 371 $\mathrm{M}^{\circ}+4 \mathrm{Cl}-2 \mathrm{CH}_{3}$ (20), $352 \mathrm{M}^{\circ+}$ $\mathrm{TiCl}_{4}(100)$

$582 \mathrm{M}^{\circ}+(20), 565$

$\mathrm{M}^{\circ}+\mathrm{CH}_{3}(15), 545$

$\mathrm{M}^{\circ}+\mathrm{Cl}(20), 508$

$\mathrm{M}^{\circ}+2 \mathrm{Cl}(20), 472$

$\mathrm{M}^{\circ}+3 \mathrm{Cl}$ (25), 458

$\mathrm{M}^{\circ}+-4 \mathrm{Cl}-\mathrm{CH}_{3}(15)$, $393 \mathrm{M}^{\circ}+-\mathrm{TiCl}_{4}(100)$ 
active than bis (benzimidazolyl) - 4-methyl benzene titanium complexes $(\mathbf{6 1 , 6 2 )}$.

GPC analysis of the polyethylenes produced by benzimidazole based complexes revealed that the symmetric catalysts systems were capable to produce resins with high to very high molecular weights associated with broad or even bimodal molecular weight distributions. The bimodality may arise from the fact that the MAO counterion induces the necessary dissymmetry of the active sites in the activation process ${ }^{46}$.

The molecular weight $M_{w}$ of the polymer produced with $\mathbf{5 5}$ / MAO was determined to be 1.3 $\times 10^{6} \mathrm{~g} / \mathrm{mol},(P D=19.2)$ (see Figure 13).

The molecular weight $\mathrm{M}_{\mathrm{w}}$ and polydispersity of the polymer produced with catalyst systems 35 / MAO, 41/ MAO, 49/MAO and 58 / MAO was

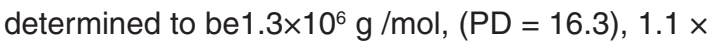
$10^{6} \mathrm{~g} / \mathrm{mol}$, (PD = 8.4), 4.4.37 $\times 10^{5} \mathrm{~g} / \mathrm{mol},(P D=9.1)$, and $3.3 \times 10^{6} \mathrm{~g} / \mathrm{mol},(\mathrm{PD}=10.2)$ respectively.

Differential scanning calorimetric (DSC) measurements for representative samples of polyethylenes produced with bis-(benzimidazolyl, benzothiazolyl, and benzoxazolyl) zirconium complexes revealed that the catalyst systems were capable to produce high density polyethylenes with melting temperatures $>135^{\circ} \mathrm{C}$. The crystallization temperatures of the polymers range from $118-125^{\circ} \mathrm{C}$ and the polymers have high degrees of crystallinities. For example, DSC curves for polyethylene produced with the catalysts 55 / MAO (see Figures 14) show melting temperatures $137.5^{\circ} \mathrm{C}$ and crystallization temperatures of $120.3^{\circ} \mathrm{C}$.

\section{EXPERIMENTAL}

All experimental work was routinely carried out using Schlenk technique unless otherwise stated. Anhydrous and purified argon was used as inert gas. n-Pentane, diethyl ether, toluene and tetrahydrofuran were purified by distillation over $\mathrm{Na} / \mathrm{K}$ alloy. Diethyl ether was additionally distilled over lithium aluminium hydride. Methylene chloride was dried with phosphorus pentoxide and additionally with calcium hydride. Methanol and ethanol were dried over magnesium. Deuterated solvents $\left(\mathrm{CDCl}_{3}\right.$,
DMSO- $d_{6}$ ) for NMR spectroscopy were stored over molecular sieves (3ú). Methylalumoxane (30\% in toluene) was purchased from Crompton (Bergkamen) and Albemarle (Baton Rouge, USA / Louvain - La Neuve, Belgium). Ethylene (3.0) and argon (4.8/5.0) were supplied by Rießner Company (Lichtenfels). All other starting materials were commercially available and were used without further purification. The titanium adducts were synthesized via published procedures ${ }^{47}$

\section{NMR spectroscopy}

The spectrometer Bruker ARX 250 was available for recording the NMR spectra. The samples were prepared under inert atmosphere (argon) and routinely recorded at $25^{\circ} \mathrm{C}$. The chemical shifts in the ${ }^{1} \mathrm{H}$ NMR spectra are referred to the residual proton signal of the solvent $\left(\mathrm{d}=7.24 \mathrm{ppm}\right.$ for $\mathrm{CDCl}_{3}, \mathrm{~d}=$ 2.50 ppm for DMSO- $d_{6}$ ) and in ${ }^{13} \mathrm{C}$ NMR spectra to the solvent signal $\left(d=77.0 \mathrm{ppm}\right.$ for $\mathrm{CDCl}_{3}, \mathrm{~d}=39.5$ ppm for DMSO- $d_{6}$ ).

\section{Mass spectrometry}

Mass spectra were routinely recorded at the Zentrale Analytik of the University of Bayreuth with a VARIAN MAT CH-7 instrument (direct inlet, EI, E $=70 \mathrm{eV}$ ) and a VARIAN MAT 8500 spectrometer.

\section{Gel permeation chromatography (GPC)}

GPC measurements were routinely performed by SABIC Company (Riyadh, Saudi Arabia).

\section{Elemental analysis}

Elemental analyses were performed with a VarioEI III CHN instrument. The raw values of the carbon, hydrogen, and nitrogen contents were multiplied with calibration factors (calibration compound: acetamide).

\section{General procedures for the syntheses of the complexes}

\section{Syntheses of organic compounds 1-31}

A diamine compound $(0.05 \mathrm{~mol})$ was mixed with a dicarboxylic acid or an acid anhydride $(0.025 \mathrm{~mol})$ and the mixture was poured in $50 \mathrm{ml}$ of preheated $\left(100^{\circ} \mathrm{C}\right)$ polyphosphoric acid. The mixture was stirred and heated at $175^{\circ} \mathrm{C}$ for $3-5$ hours. The reaction mixture was then poured into ice cold water and allowed to stand overnight. The precipitate was 
removed by filtration and washed several times with diluted sodium hydrogen carbonate solution and finally with water. The reaction product was then air dried and weighed. The products were characterized by NMR and mass spectrometry (Table 3 ) and elemental analyses (Table 32).

\section{Titanium complexes 32-62}

To $0.87 \mathrm{~g},(2.6 \mathrm{mmol}) \mathrm{TiCl}_{4}(\mathrm{THF})_{2}$ in dichloromethane was added $2.6 \mathrm{mmol}$ of the solid ligand. The reaction mixture was stirred over night at room temperature; the solid formed was collected by filtration under reduced pressure and washed several times with dichloromethane, then with pentane, dried in vacuo and weighed. The products were characterized by NMR and mass spectroscopy (Table 3), and by elemental analyses (Table 1).

\section{Polymerization of ethylene}

An amount of $2-5 \mathrm{mg}$ of the desired complex was suspended in $5 \mathrm{ml}$ of toluene. Methylaluminoxane (30\% in toluene) was added resulting in an immediate color change. The mixture was added to a 1 I Schlenk flask filled with $250 \mathrm{ml}$ $\mathrm{n}$-pentane. This mixture was transferred to a 1 I Büchi laboratory autoclave under inert atmosphere and thermostated. An ethylene pressure of 10 bar was applied for one hour. The polymer was filtered over a frit, washed with diluted hydrochloric acid, water, and acetone, and finally dried in vacuo.

\section{CONCLUSIONS}

Mononuclear transition metal complexes with hetero atoms in the ligand system can offer a big advantage. After activation with MAO, more than one active center can be generated and as a consequence bimodal or multimodal resins are produced in catalytic ethylene polymerization reactions. Obviously the hetero atoms of the activated catalysts undergo different interactions with the Lewis acidic moieties of MAO. Structureproperty-relationship studies indicate that the nature of the hetero atom and steric and electronic conditions in the coordination sphere are strongly influence the performance of such catalysts.

\section{ACKNOWLEDGEMENTS}

The author thanks SABIC Company (Riyadh, Saudi Arabia) for GPC measurements and University of Bayreuth (Germany) for the laboratory facilities.

\section{REFERENCES}

1. Lever, A. B. P.; Ramaswamy, B. S.; Simonsen, S. H.; Thompson, L. K. Can. J. Chem. 1970, 48, 3076- 3088.

2. Rendell J. C.; Thompson, L. K. Can. J. Chem. 1979, 57,1-7.

3. Thompson, L.K.; Rendell, J. C.; Wellon, G.C. Can. J. Chem. 1982, 60, 514-520.

4. Duff, E. J.; Hughes M. N.; Rutt, K. J. J. Chem. Soc. A. 1969, 2101-2105.

5. Campell, M. J. M.; Card, D. W.; Grzeskowiak, R.; Goldstein M. J. Chem. Soc. A, 1970, 672675.

6. Chan, N. N. Y.; Goodgame, M.; Weeks, M.J. J. Chem. Soc. A. 1968, 2499-2501.

7. Thompson, L. K.; Ball, R. G.; Trotter, J. Can. J. Chem. 1980, 58, 1566-1576.

8. Duff, E. J.; Hughes, M. N.; Rutt, K. J. J. Chem. Soc. A. 1968, 2354-2357.

9. Livingstone, S.E.; Nolan, J. D. J. Chem. Soc.
Dalton Trans.1972, 218-223.

10. Salameh, A. S.; Tayim, H. A. Polyhedron 1982 , 6, 543-548.

11. Wang, S.; Cui, Y.; Tan, R.; Luo, Q.; Shi, J.;Wu, Q. Polyhedron 1994, 11, 1661-1668.

12. Wang, J.; Zhu, Y.; Wang, S.; Gao, Y.; Shi, Q. Polyhedron 1994, 13, 1405-1409.

13. Holz, R. C.; Thomson, L. C. Inorg. Chem. 1988, 27, $4640-4644$.

14. Wang, S. X.; Zhu, Y.; Zhang, F. G.; Wang, Q. Y.; Wang, L. F. Polyhedron 1992, 11, 19091915.

15. Addison, A. D.; Burman, S.; Wahlgren, C. B.; Raijan, O. A.; Rowe, T. W.; Sinn, E., J. Chem. Soc. Dalton Trans. 1987, 2621 - 2630.

16. Ruttimann, S.; Moreau, C. M.; Williams, A. F.; Bernardinelli, G.; Addison, A. W. Polyhedron 1992, 11, 635-646.

17. Nelson, S. M.; Esho, F. S.; Drew, M. G. B. J. 
Chem. Soc. Dalton Trans. 1982, 407-415.

18. Shashikala, N.; Gayathri, V.; Gowda, N. M. N.; Reddy, G. K. N. J. Indian Chem. Soc. 1989, 66, 537-540.

19. Sanni, S. B.; Behm, H. J.; Benrskens, P. T.; Albada, G. A. V.; Reedijk, J.; Lenstra, A. T.H.; Addison, A. W.; Palaniandavar, M. J. J. Chem. Soc. Dalton Trans. 1988, 1429-1435.

20. Wellon, G. C.; Bautista, D. V.; Thompson, L. K.; Hartstock, F. W. Inorg. Chim. Acta. 1983, 75, 271-276.

21. Breslow, R.; Hunt, J.T.; Smiley, R.; Tamowski, T. J. Am. Chem. Soc. 1983, 105, 5337 -5342.

22. Beer, R. H.; Tolmann, W. B.; Bott, S. G.; Lippard, S. J. Inorg. Chem. 1989, 28, 4557-4558.

23. Winter, J. A.; Caruso, D.; Shepherd, R. E. Inorg. Chem. 1988, 27, 1086-1089.

24. Jin, G.; Chen, F. CN 101089022A (2007).

25. Britovsek, G. J. P.; Gibson, V. C.; Wass, D. F. Angew. Chem. Int. Ed. Engl. 1999, 38, 428447.

26. Ittel, S. D.; Johnson, L. K.; Brookhart, M. Chem. Rev. 2000, 100, 1169-1204.

27. Zhang, W.; Sun, W.-H.; Zhang, S.; Hou, J.; Wedeking, K.; Schultz, S.; Fröhlich, R.; Song, H. Organometallics 2006, 25, 1961-1969.

28. Kaminsky, W.; Fernandes, M. Polyolefins 2015, 2, 1-19.

29. Redshaw, C.; Tang, Y. Chem. Soc. Rev. 2012, 41, 4484 - 4510.

30. Baier, M.C.; Zuideveld, M.A.; Mecking, S. Angew. Chem. Int. Ed. 2014, 53, 9722- 9744

31. Tomov, A. K.; Gibson, V. C.; Zaher, D.; Elsegood, M. R. J.; Dale, S. H. Chem. Commun. 2004, 1956-1957.
32. Cho, H. Y.; Tarte, N. H.; Cui, L.; Hong, D. S.; Woo, S. I.; Gong, Y.-D. Macromol. Chem. Phys. 2006, 207, 1965-1971.

33. Elagab, H. A.; Alt, H. G. Inorg. Chim. Acta. 2015, 428, $100-111$.

34. Elagab, H. A.; Alt, H. G. Eur. Poly. J. 2015, 68, 385- 397.

35. Elagab, H. A.; Alt, H. G. Inorg. Chim. Acta. 2015, 431,266 - 275.

36. Elagab, H. A.; Alt, H. G. Jordan Journal of Chemistry 2015, 10, 1-19.

37. Elagab, H. A.; Alt, H. G. Jordan Journal of Chemistry 2015, 10, 41-57.

38. Elagab, H. A.; Alt, H. G. Eur. Poly. J. 2015, 71, 85- 98.

39. Elagab, H. A.; Alt, H. G. Inorg. Chim. Acta. 2015, 437, 26 - 37.

40. Phillips, M. A. J. Chem. Soc. 1928, 23932399.

41. Rai, C.; Braunwarth, J. B. J. Org. Chem. 1961, 26, $3434-3436$.

42. Bochmann, M.; Wilson, L. M. J. Chem. Soc. Chem. Commun. 1986, 21, 1610-1611.

43. Jordan, R. F.; Bajgur, C. S.; Dasher, W. E.; Rheingold A. L. Organometallics1987, 6, 1041-1051.

44. Seitz, M.; Milius, W.; Alt, H. G. J. Mol. Catal. A. 2007, 261, 246-153.

45. Oouchi, K.; Mitani, M.; Hayakawa, M.;Yamada, T. Macromol. Chem. Phys. 1996, 197, 1545.

46. Yang, M; Yan, Wei-d.;Shen, Xiao-I.; Mu,B.; Wang, Bai-q. Chinese J. Poly. Sci. 2008, 26, 415-423.

47. Manzer, L. E., Inorganic Synthesis 1982, 21, 135-140. 